\title{
Simultaneous aerosol mass spectrometry and chemical ionisation mass spectrometry measurements during a biomass burning event in the UK: insights into nitrate chemistry
}

\author{
Ernesto Reyes-Villegas ${ }^{1}$, Michael Priestley ${ }^{1}$, Yu-Chieh Ting ${ }^{1}$, Sophie Haslett ${ }^{1}$, Thomas Bannan $^{1}$, Michael Le Breton ${ }^{1, \text { a }}$, \\ Paul I. Williams ${ }^{1,2}$, Asan Bacak ${ }^{1}$, Michael J. Flynn ${ }^{1}$, Hugh Coe ${ }^{1}$, Carl Percival ${ }^{1, b}$, and James D. Allan ${ }^{1,2}$ \\ ${ }^{1}$ School of Earth, Atmospheric and Environmental Sciences, The University of Manchester, \\ Manchester, M13 9PL, UK \\ ${ }^{2}$ National Centre for Atmospheric Science, The University of Manchester, Manchester, M13 9PL, UK \\ ${ }^{a}$ now at: Department of Chemistry \& Molecular Biology, University of Gothenburg, \\ 40530 Gothenburg, Sweden \\ bnow at: Jet Propulsion Laboratory, 4800 Oak Grove Drive, Pasadena, CA 91109, USA
}

Correspondence: Ernesto Reyes-Villegas (ernesto.reyesvillegas@manchester.ac.uk)

Received: 29 June 2017 - Discussion started: 11 July 2017

Revised: 10 January 2018 - Accepted: 29 January 2018 - Published: 23 March 2018

\begin{abstract}
Over the past decade, there has been an increasing interest in short-term events that negatively affect air quality such as bonfires and fireworks. High aerosol and gas concentrations generated from public bonfires or fireworks were measured in order to understand the night-time chemical processes and their atmospheric implications. Nitrogen chemistry was observed during Bonfire Night with nitrogen containing compounds in both gas and aerosol phases and further $\mathrm{N}_{2} \mathrm{O}_{5}$ and $\mathrm{ClNO}_{2}$ concentrations, which depleted early next morning due to photolysis of $\mathrm{NO}_{3}$ radicals and ceasing production. Particulate organic oxides of nitrogen (PONs) concentrations of $2.8 \mu \mathrm{g} \mathrm{m}^{-3}$ were estimated using the $m / z$ 46:30 ratios from aerosol mass spectrometer (AMS) measurements, according to previously published methods. Multilinear engine 2 (ME-2) source apportionment was performed to determine organic aerosol (OA) concentrations from different sources after modifying the fragmentation table and it was possible to identify two PON factors representing primary (pPON_ME2) and secondary (sPON_ME2) contributions. A slight improvement in the agreement between the source apportionment of the AMS and a collocated AE-31 Aethalometer was observed after modifying the prescribed fragmentation in the AMS organic spectrum (the fragmentation table) to determine PON sources, which resulted in an $r^{2}=0.894$ between biomass burning organic aerosol (BBOA) and $b_{\text {abs_470wb }}$ compared to an $r^{2}=0.861$
\end{abstract}

obtained without the modification. Correlations between OA sources and measurements made using time-of-flight chemical ionisation mass spectrometry with an iodide adduct ion were performed in order to determine possible gas tracers to be used in future ME-2 analyses to constrain solutions. During Bonfire Night, strong correlations $\left(r^{2}\right)$ were observed between BBOA and methacrylic acid (0.92), acrylic acid $(0.90)$, nitrous acid $(0.86)$, propionic acid, $(0.85)$ and hydrogen cyanide (0.76). A series of oxygenated species and chlorine compounds showed good correlations with SPON_ME2 and the low volatility oxygenated organic aerosol (LVOOA) factor during Bonfire Night and an event with low pollutant concentrations. Further analysis of pPON_ME2 and sPON_ME2 was performed in order to determine whether these PON sources absorb light near the UV region using an Aethalometer. This hypothesis was tested by doing multilinear regressions between $b_{\text {abs_470wb }}$ and BBOA, sPON_ME2 and pPON_ME2. Our results suggest that sPON_ME2 does not absorb light at $470 \mathrm{~nm}$, while pPON_ME2 and LVOOA do absorb light at $470 \mathrm{~nm}$. This may inform black carbon (BC) source apportionment studies from Aethalometer measurements, through investigation of the brown carbon contribution to $b_{\text {abs_}} 470 \mathrm{wb}$. 


\section{Introduction}

Exposure to combustion aerosols has been associated with a range of negative health effects. In particular, wood smoke aerosols have been shown to present respiratory and cardiovascular health effects (Naeher et al., 2007). Bonfires and fireworks are one of the main sporadic events with high emissions of atmospheric pollutants (Vassura et al., 2014; Joshi et al., 2016); even when these high emissions only last a couple of hours, high pollutant concentrations may instigate adverse effects on human health (Moreno et al., 2007; Godri et al., 2010) and severely reduce visibility (Vecchi et al., 2008). Ravindra et al. (2003) found that the short-term exposure to air pollutants increases the likelihood of acute health effects.

Due to these adverse effects, different studies have been performed to analyse air pollution during important festivities around the world, for instance New Year's Eve celebrations (Drewnick et al., 2006; Zhang et al., 2010), the Lantern Festival in China (Wang et al., 2007) and Diwali festival in India (Pervez et al., 2016) as well as football matches such as during the Bundesliga in Mainz, Germany in 2012 (Faber et al., 2013). In the UK, the Bonfire Night festivity takes place on 5 November to commemorate Guy Fawkes' unsuccessful attempt to destroy the Houses of Parliament in 1605 (Ainsworth, 1850). During this celebration, bonfires, usually followed by fireworks, are lit domestically and on a larger scale communally in public parks. Different studies have been carried out to assess the air pollution during Bonfire Night in the UK; for instance targeting the particle size distribution (Colbeck and Chung, 1996), investigating $\mathrm{PM}_{10}$ concentrations in different cities around the UK during Bonfire Night celebrations (Clark, 1997) and measuring dioxins in ambient air in Oxford (Dyke et al., 1997); polycyclic aromatic hydrocarbons were measured in Lancaster in 2000 (Farrar et al., 2004), potentially toxic elements were measured and their association with health risks was assessed in London (Hamad et al., 2015).

Receptor modelling has been widely used to determine organic aerosol (OA) sources in urban environments. However, it has been used in just a small number of studies with sporadic events of high pollutant concentrations. For instance, Vecchi et al. (2008) were the first to analyse measurements taken during firework displays using positive matrix factorisation (PMF). Tian et al. (2014) did a PMF analysis of $\mathrm{PM}_{2.5}$ components, identifying five different sources: crustal dust, coal combustion, secondary particles, vehicular exhausts and fireworks. In Riccione, Italy, Vassura et al. (2014) determined that levoglucosan, organic carbon (OC), polycyclic aromatic hydrocarbons (PAHs), $\mathrm{Al}$ and $\mathrm{Pb}$, emitted from bonfires during St. Joseph's Eve, can be used as markers for bonfire emissions.

Particulate organic oxides of nitrogen (PONs), a term we use here to encompass nitro-organics and organic nitrates, have been found to absorb light near the ultraviolet (UV) region (Mohr et al., 2013) and to present potential toxic- ity to human health (Fernandez et al., 1992; Qingguo et al., 1995). PONs also act as a $\mathrm{NO}_{x}$ reservoir at night, releasing $\mathrm{NO}_{x}$ concentrations when the sun rises with the possibility of increasing $\mathrm{O}_{3}$ production (Perring et al., 2013; Mao et al., 2013). PONs are important components of OAs; for instance Day et al. (2010), in measurements taken during winter at an urban location, found that PON concentrations accounted for up to $10 \%$ of organic matter. Kiendler-Scharr et al. (2016) concluded that, on a continental scale, PONs represent 34 to $44 \%$ of aerosol nitrate. Organic oxides of nitrogen can be categorised, according to their origin, into two types: primary and secondary. Primary organic nitrates are related to combustion sources (Zhang et al., 2016) such as fossil fuels (Day et al., 2010) and biomass burning emissions (Kitanovski et al., 2012; Mohr et al., 2013). Secondary organic oxides of nitrogen are produced in the atmosphere, for example when $\mathrm{NO}_{3}$ reacts with unsaturated hydrocarbons ( $\mathrm{Ng}$ et al., 2017). Nitrophenols are produced from reactions of phenols, both during the day reacting with $\mathrm{OH}+\mathrm{NO}_{2}$ and at night reacting with $\mathrm{NO}_{3}+\mathrm{NO}_{2}$ (Harrison et al., 2005; Yuan et al., 2016).

The Aethalometer (Magee Scientific, USA) has been widely used to measure light absorbing carbon, proving to be a robust instrument that can operate in a variety of environments and is currently being used at many different locations around the world. The European Environment Agency, in a technical report published in 2013 (EEA, 2013), states that there are at least 11 European countries using Aethalometers. The UK has a black carbon (BC) network comprising of 14 sites covering a wide range of monitoring sites (https://uk-air. defra.gov.uk/networks/network-info?view=_ukbsn) and, in 2016, India started a BC network with 16 Aethalometers (Laskar et al., 2016). Commonly, Aethalometers have been used to separate sources of light-absorbing aerosols following Sandradewi et al. (2008). The approach separates absorption from traffic, predominately resulting from $\mathrm{BC}$, which absorbs light in the infrared region and from wood burning, which includes $\mathrm{BC}$ and absorbing organic matter that also absorbs near the UV region. The Aethalometer model is based on the differences in aerosol absorption, using the absorption Ångström exponent, at a specific wavelength of light chosen to run the model. Absorption Ångström exponent values range from 0.8 to 1.1 for traffic and $0.9-3.5$ for wood burning (Zotter et al., 2017). It is known that brown carbon (BrC) is organic matter capable of absorbing light near the UV region (Bones et al., 2010; Saleh et al., 2014) and that PONs are a potential contributor to $\mathrm{BrC}$ (Mohr et al., 2013). However, the mechanistic principle that links this behaviour to wood burning has not been completely resolved and there may be other sources such as secondary organic aerosols (SOAs) that can absorb near the UV region.

Here we present an analysis performed on data collected during Bonfire Night celebrations in Manchester, UK (29 October to 10 November 2014) using a compact time-offlight aerosol mass spectrometer (cToF-AMS) and a highresolution time-of-flight chemical ionisation mass spectrom- 
eter (HR-ToF-CIMS) along with other instruments to measure both aerosols and gaseous pollutants with the aim of understanding the night-time chemical processes and their atmospheric implications. Very high concentrations of pollutants occurred as a result of the meteorological conditions, which presented a good opportunity to investigate the detailed phenomenon as a case study, particularly the possibility to determine PON concentrations, their nature and interaction with Aethalometer measurements.

\section{Methods}

\subsection{Site and instrumentation}

Online measurements of aerosols and gases were taken from ambient air, between 29 October and 10 November 2014, at a rooftop location at the University of Manchester $\left(53.467^{\circ} \mathrm{N}\right.$, $2.232^{\circ} \mathrm{W}$ ), in order to quantify atmospheric pollution during Bonfire Night celebrations on and around 5 November. Figure S1 in the Supplement shows a map with the location of the monitoring site and nine public parks where bonfire and/or fireworks were displayed around greater Manchester. This is the same dataset presented by Liu et al. (2017).

A cToF-AMS (hereafter AMS) was used to perform $5 \mathrm{~min}$ measurements of $\mathrm{OA}$, sulfate $\left(\mathrm{SO}_{4}^{2-}\right)$, nitrate $\left(\mathrm{NO}_{3}^{-}\right)$, ammonium $\left(\mathrm{NH}_{4}^{+}\right)$and chloride $\left(\mathrm{Cl}^{-}\right)$(Drewnick et al., 2005). This version of AMS provides unit mass resolution mass spectra information. A HR-ToF-CIMS (hereafter CIMS) was used to measure gas phase concentrations, using iodide as a reagent (Lee et al., 2014). The methodology to calculate gas phase concentrations from CIMS measurements have been described by Priestley et al. (2018). An Aethalometer (model AE31, Magee Scientific) measured light absorption at seven wavelengths $(370,450,571,615,660,880$ and $950 \mathrm{~nm})$ and a multi-angle absorption photometer (MAAP; Thermo model 5012) measured BC concentrations (Petzold et al., 2002). $\mathrm{NO}_{x}, \mathrm{CO}, \mathrm{O}_{3}$ and meteorology data were downloaded from Whitworth observatory (http://www.cas.manchester.ac. uk/restools/whitworth/data/), which were measured at the same location. From 31 October to 10 November, a catalytic stripper was attached to the AMS, switching every 30 min between direct measurements and through the catalytic stripper. These measurements were performed as part of a different experiment (Liu et al., 2017). In the present study we used the AMS data from the direct measurements only, aerosol and gas data from other instruments were averaged to AMS sampling times.

\subsection{Source apportionment}

\subsubsection{Aethalometer model}

The aerosol light absorption depends on the wavelength and may be used to apportion BC from traffic and wood burning from Aethalometer measurements as proposed by San- dradewi et al., 2008. The absorption coefficients $\left(b_{\mathrm{abs}}\right)$ are related to the wavelengths at which the absorptions are measured $(\lambda)$ and the Angström absorption exponents $(\alpha)$ with the relationship $b_{\text {abs }} \propto \lambda^{\alpha i}$, thus the following equations can be solved:

$\frac{b_{\text {abs_470tr }}}{b_{\text {abs_950tr }}}=\left(\frac{470}{950}\right)^{-\alpha_{\mathrm{tr}}}$,

$\frac{b_{\text {abs_470wb }}}{b_{\text {abs_950wb }}}=\left(\frac{470}{950}\right)^{-\alpha_{\mathrm{wb}}}$,

$b_{\text {abs }}\left(470_{\text {nm }}\right)=b_{\text {abs_4 } 40 \text { tr }}+b_{\text {abs_4 } 470 \mathrm{wb}}$,

$b_{\text {abs }}\left(950_{\mathrm{nm}}\right)=b_{\text {abs_950tr }}+b_{\text {abs_950wb }}$.

Here, it is possible to calculate the wood burning (wb) and traffic (tr) contributions to BC at 470 and $950 \mathrm{~nm}$ as used in previous studies (Crilley et al., 2015; Harrison et al., 2012). Wavelengths of 470 and $950 \mathrm{~nm}$ were chosen as Zotter et al. (2017) determined that using this pair of wavelengths resulted in fewer residuals compared with using the wavelengths 470-880 and 370-880 nm. Before the Aethalometer model was applied, the absorption coefficients $\left(b_{\mathrm{abs}}\right)$ needed to be corrected following Weingartner et al. (2003) as attenuation is affected by scattering and loading variations. The following parameters were calculated: multiple scattering constant $C=3.16$ and filter loading factors $(f)$ of 1.49 and 1.28 for the wavelengths 470 and $950 \mathrm{~nm}$, respectively. Refer to Sect. S3 in the Supplement for detailed information.

\subsubsection{Particulate organic oxides of nitrogen (PONs)}

Concentrations of PONs were calculated following the method proposed by Farmer et al. (2010) and the considerations used by Kiendler-Scharr et al. (2016). This method has been previously used in studies looking at aerosols from biomass burning (Tiitta et al., 2016; Zhu et al., 2016; Florou et al., 2017). Equation (5) calculates the PON fraction $\left(X_{\mathrm{PON}}\right)$, using the signals at $\mathrm{m} / \mathrm{z} 30$ and $\mathrm{m} / \mathrm{z} 46$ to calculate $m / z$ ratios $46: 30$ from AMS measurements $\left(R_{\text {meas }}\right)$, from ammonium nitrate calibrations $\left(R_{\mathrm{cal}}\right)$, and from organic nitrogen $\left(R_{\mathrm{ON}}\right)$ to quantify PON concentrations.

$X_{\mathrm{PON}}=\frac{\left(R_{\text {meas }}-R_{\mathrm{Cal}}\right)\left(1+R_{\mathrm{ON}}\right)}{\left(R_{\mathrm{ON}}-R_{\mathrm{cal}}\right)\left(1+R_{\mathrm{meas}}\right)}$,

where ratios from ammonium nitrate calibrations $R_{\mathrm{cal}}=0.5$; $R_{\text {meas }}=m / z$ 46:30 ratio from measurements; $m / z \quad 46: 30$ ratio from $\mathrm{ON} R_{\mathrm{ON}}=0.1$, Following Kostenidou et al. (2015) consideration, $R_{\mathrm{ON}}=0.1$ was calculated as the minimum $m / z$ 46:30 ratio observed. A $R_{\mathrm{ON}}$ value of 0.1 has been used in previous studies (Kiendler-Scharr et al., 2016; Tiitta et al., 2016).

$\mathrm{PON}=X_{\mathrm{PON}} \cdot \mathrm{NO}_{3}^{-}$

Finally, Eq. (6) calculates PON concentrations $\left(\mu \mathrm{g} \mathrm{m}^{-3}\right)$ where $\mathrm{NO}_{3}^{-}$is the total nitrate measured by the cToF-AMS 
The method proposed by Farmer et al. (2010) is based on HR-ToF-AMS measurements where $m / z, 30$ represents the $\mathrm{NO}^{+}$ion and $m / z 46$ the $\mathrm{NO}_{2}^{+}$ion, while the cToF-AMS gives unit mass resolution mass spectra information, hence there is the possibility to have interference of the $\mathrm{CH}_{2} \mathrm{O}^{+}$ion at $m / z$ 30. However, when analysing mass spectra from previous laboratory and ambient studies using HR-ToF-AMS to investigate biomass burning emissions, we can confirm that the signal of $\mathrm{CH}_{2} \mathrm{O}^{+}$at $m / z 30$ is low compared to signals at $\mathrm{m} / z$ 's 29 and 31, while in this study $\mathrm{m} / \mathrm{z} 30$ is the main signal (Fig. 5c). Hence, in this study an interference of $\mathrm{CH}_{2} \mathrm{O}^{+}$ at $m / z, 30$ is unlikely and if there were any interference of $\mathrm{CH}_{2} \mathrm{O}^{+}$it would be negligible. Table $\mathrm{S} 1$ in the Supplement shows $m / z 30 / 29$ and 30/31 from previous laboratory and ambient studies investigating biomass burning emissions.

Another possible interference would be the presence of mineral nitrates at $m / z 30$ (e.g. $\mathrm{KNO}_{3}$ and $\mathrm{NaNO}_{3}$ ). However, mineral nitrate salts tend to be large particles (Allan et al., 2006; Chakraborty et al., 2016) and also have a low vaporisation efficiency (Drewnick et al., 2015), which makes it unlikely to be measured by the AMS in large quantities.

\subsubsection{Multilinear engine 2 (ME-2)}

Multilinear engine 2 (ME-2; Paatero, 1999) is a multivariate solver used to determine factors governing the behaviour of a two-dimensional data matrix, which can then be interpreted as pollutant sources. ME-2 uses the same data model as PMF, which is also a receptor model that performs factorisation by using a weighted least squares approach (Paatero and Tapper, 1994).

In order to explore the solution space, ME-2 is capable of using information from previous studies, for example pollutant time series or mass spectra, as inputs to the model (named target time series and target profiles) to constrain the runs. These constraints are performed using the a-value approach, to determine the extent to which the output is allowed to vary. For example, by using an a-value of 0.1 to a specific source, the user is allowing the output to vary $10 \%$ from the input. For more details refer to Canonaco et al. (2013).

In this study, ME-2 and PMF were used through the source finder interface, (SoFi version 4.8; Canonaco et al., 2013) to identify OA sources using the suggestions made by Crippa et al. (2014) and the strategy proposed by Reyes-Villegas et al. (2016). ME-2 was performed using mass spectra (BBOA, HOA and COA) from two different studies as target profiles (TP) to constrain the runs: London (Young et al., 2015) and Paris (Crippa et al., 2013), Fig. S5 explains the labelling used to identify the different runs.

Solutions were explored with PMF using different FPEAK values (ranging from -1.0 to 1.0 with steps of 0.1 ) and ME-2 using different a-values (nine runs with the London TP and nine runs with the Paris TP) looking at 4, 5 and 6-factor solutions. Section S7.1 shows the strategy used to determine the optimal solution. Factorisation struggles to separate two or more sources if they are highly correlated, for example during stagnant conditions due to low temperatures and wind speed, which was the case during Bonfire Night 2014. The pollutants were well-mixed, making it difficult to separate the sources. Hence, four tests were performed using different time sets in order to identify the best way to perform source apportionment:

- Test 1 performs factorisation on all of the dataset.

- Test 2 (hereafter Test2) involves factorising the event before and after Bonfire Night and using mass spectra from this analysis as TP to factorise the Bonfire Night event.

- Test 3 involves factorising the Bonfire Night event and using mass spectra from this analysis as TP as applied to the complete dataset.

- Test 4 involves factorising the event before and after Bonfire Night and using mass spectra from this analysis as TP to factorise the full dataset.

PONs may exhibit covariance with other types of OA, thus their inclusion in the source apportionment analysis may improve the factorisation and highlight their co-emission with other OA types. Previous studies have quantified PON concentrations from AMS-PMF analysis to both rural and urban measurements (Sun et al., 2012; Hao et al., 2014; Xu et al., 2015; Zhang et al., 2016). In this study, an experiment was designed by modifying the fragmentation table, through the AMS analysis toolkit 1.56 , in order to identify a PON source. The fragmentation table contains the different chemical species measured by the AMS, with each row representing $m / z$ for specific species and the user can define peaks that exist in each species' partial mass spectrum with their dependency on other peaks (Allan et al., 2004). The following steps were performed to modify the fragmentation table:

- Time series of a new ratio named $R_{\mathrm{ON} \_30}$ is calculated by $R_{\mathrm{ON} \_} 30=\mathrm{PON} / \mathrm{m} / z 30$, where PON is the time series calculated in Sect. 2.2.2 and $\mathrm{m} / z 30$ is the time series of the signal at $m / z=30$ measured by the AMS.

- Using the AMS analysis toolkit, the fragmentation table is modified (in the column "frag_Organic" at $m / z$ 30) by multiplying $R_{\mathrm{ON} \_30} \cdot 30$. See Fig. S4 for a screenshot of the fragmentation table.

- PMF inputs are generated to be used in the SoFi software.

\section{Results}

\subsection{Meteorology and pollutant overview}

During Bonfire Night festivities on 5 November, a temperature of $4{ }^{\circ} \mathrm{C}$ and wind speed of $1.5 \mathrm{~m} \mathrm{~s}^{-1}$ were observed 


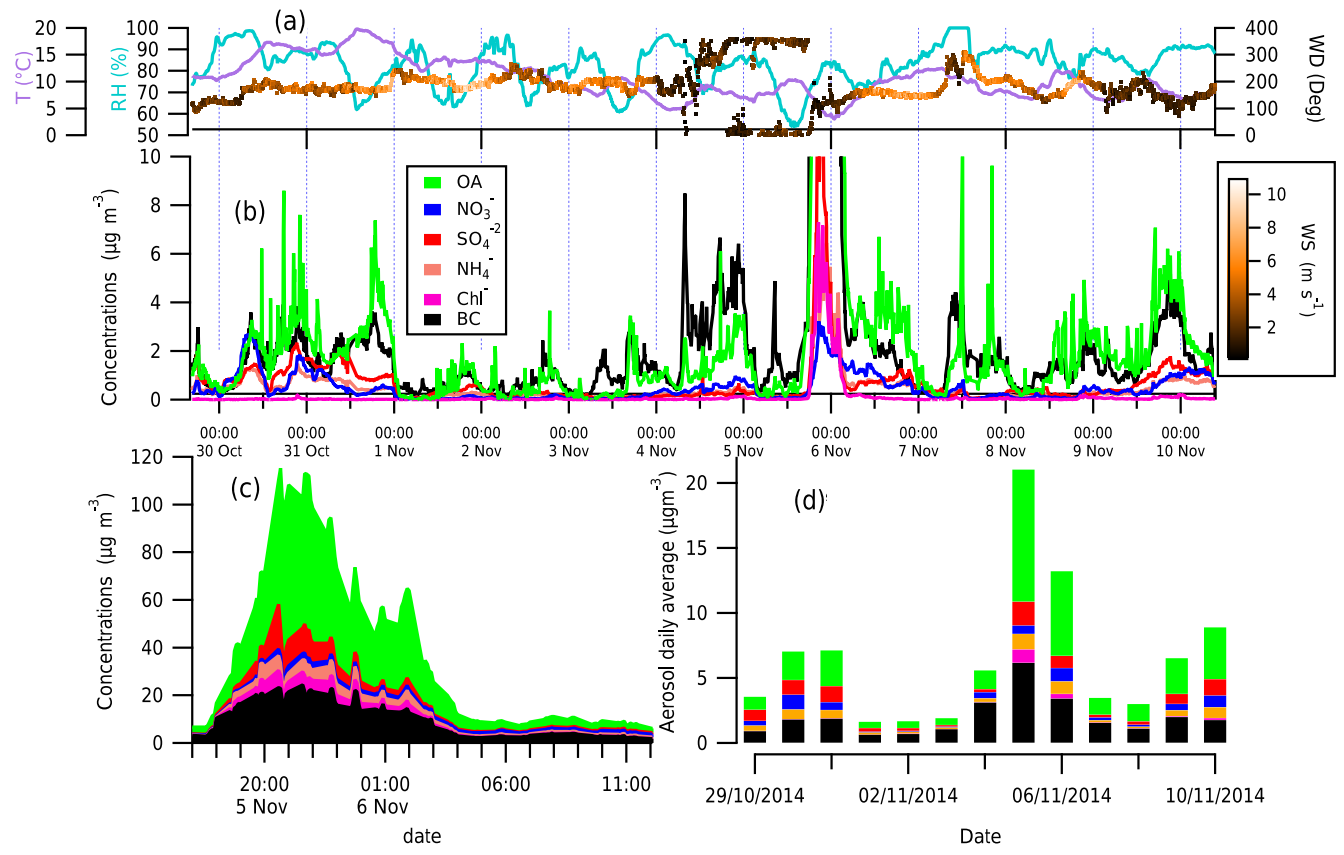

Figure 1. Meteorology (a), aerosol concentrations during all measurement periods (b). Chemical component mass concentrations during Bonfire Night plotted cumulatively (c). Daily aerosol concentrations (d).

(Fig. 1a), causing stagnant conditions which facilitated pollutant accumulation. Looking at the time series for the whole sampling time (Fig. 1b), it was possible to observe four separate events with different pollutant behaviour (marked with coloured lines over the $x$ axis in Fig. 1), driven by different meteorological conditions: one event had high secondary concentrations (HSC, yellow line) from 30 October to 1 November, which experienced a relatively high temperature of $17-20^{\circ} \mathrm{C}$; another event of low pollutant concentrations (LC, grey line) from 1 to 3 November was observed when continental air masses were present; Bonfire Night (bfo, blue line), with a temperature of $4{ }^{\circ} \mathrm{C}$; and a winterlike episode (WL, purple line) from 8 to 10 November, with temperatures of $5-6^{\circ} \mathrm{C}$ and high primary pollutant concentrations. Figure S3 shows back trajectories of the different events.

Aerosol concentrations during Bonfire Night were particularly high (Fig. 1c), with the highest peak concentrations of $65.0,19.0,6.8,6.0,5.9$ and $3.2 \mu \mathrm{g} \mathrm{m}^{-3}$ for $\mathrm{OA}, \mathrm{BC}, \mathrm{SO}_{4}$, $\mathrm{Cl}, \mathrm{NH}_{4}$ and $\mathrm{NO}_{3}$ respectively measured around 20:30 LT (local time) on 5 November. It is worth noting how high these concentrations are compared to concentrations before and after Bonfire Night (Fig. 1b), where aerosol concentrations ranged from 0.5 to $7.0 \mu \mathrm{g} \mathrm{m}^{-3}$. Measured $\mathrm{PM}_{1}$ concentrations (sum of $\mathrm{BC}$, organic and inorganic aerosols) of $115 \mu \mathrm{g} \mathrm{m}^{-3}$ (Fig. 1c) were observed during Bonfire Night.

Looking at the daily concentrations (Fig. 1d), it is possible to observe $\mathrm{PM}_{1}$ daily concentrations of $25 \mu \mathrm{g} \mathrm{m}^{-3}$ on Bonfire Night compared to the low concentrations observed between 1 and 2 November with concentrations ranging be- tween 3 and $4 \mu \mathrm{g} \mathrm{m}^{-3}$. The impact of the emissions during Bonfire Night is present even during the next day with $\mathrm{PM}_{1}$ concentrations of $14 \mu \mathrm{g} \mathrm{m}^{-3}$.

Gas phase pollutants were measured at the Whitworth observatory. Figure 2 shows high $\mathrm{SO}_{2}, \mathrm{CO}$ and $\mathrm{NO}_{x}$ concentrations during Bonfire Night; these primary pollutants are wellknown combustion-related pollutants. The high $\mathrm{SO}_{2}$ concentrations during Bonfire Night are expected as solid fuels such as wood emit $\mathrm{SO}_{2}$ when burned. This can also explain the $\mathrm{SO}_{2}$ peak on the night of 10-11 November when $\mathrm{SO}_{2}$ concentrations may be related to solid fuels used for domestic heating as a result of the low temperatures $\left(6^{\circ} \mathrm{C}\right)$. $\mathrm{CO}$ and $\mathrm{NO}$ were present at higher concentrations during Bonfire Night compared to previous days with concentrations reaching $1600 \mathrm{ppb}(\mathrm{CO})$ and $99 \mathrm{ppb}(\mathrm{NO})$ during Bonfire Night compared to 1 November with concentrations of $230 \mathrm{ppb}$ of $\mathrm{CO}$ and $16 \mathrm{ppb}$ of NO. Some $\mathrm{O}_{3}$ concentrations were measured during Bonfire Night but given the very high NO concentrations, these are considered to be an interference with the measurement.

\subsection{Bonfire Night analysis}

\subsubsection{Traffic and wood burning contributions to BC}

OA concentrations started increasing at 19:30 LT, while BC concentrations started increasing $2 \mathrm{~h}$ earlier around 17:00 LT (Fig. 1c). This rise in BC concentrations may be due to bonfire emissions, although they may also be related to traffic 


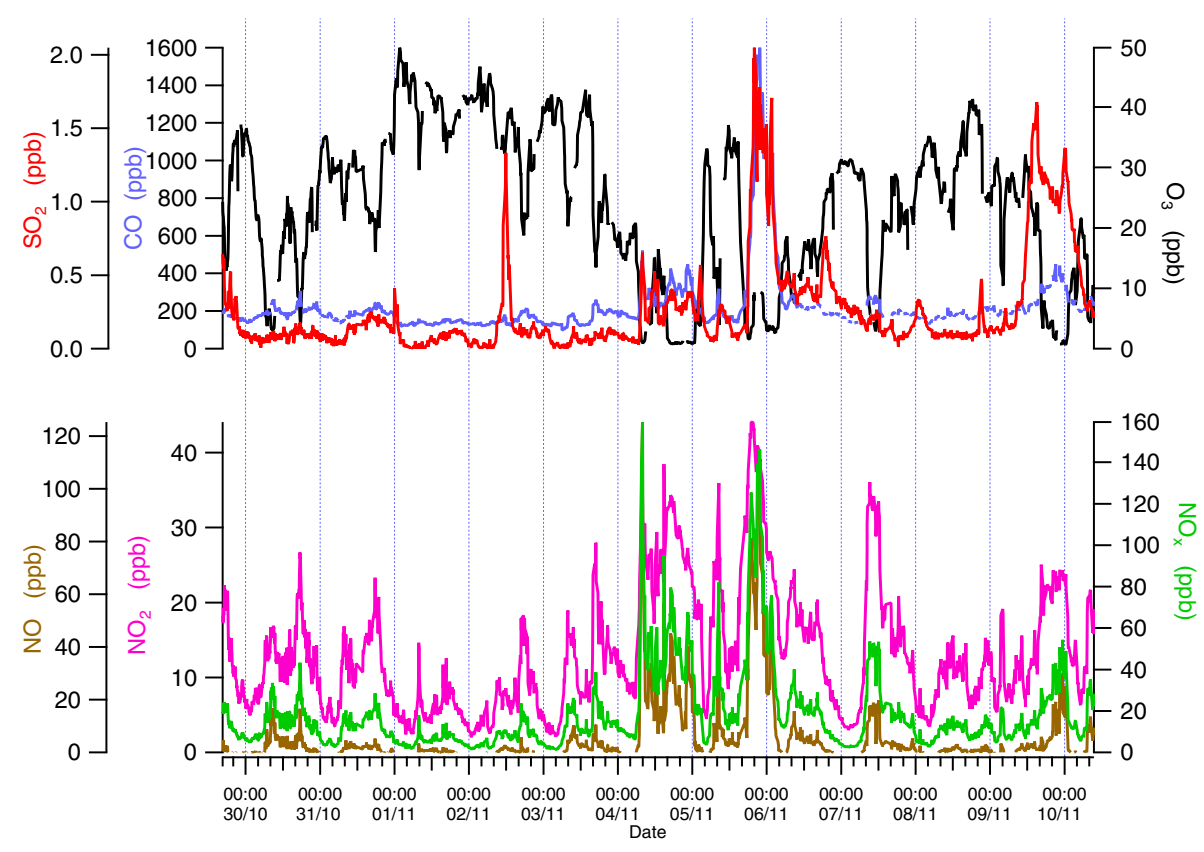

Figure 2. Time series of gases measured at Whitworth observatory.

emissions; thus the Aethalometer model was used to identify both traffic and wood burning contributions to BC.

Once $b_{\mathrm{abs}}$ values are corrected, equations shown in Sect. 2.2.1 are used to apply the Aethalometer model, with Ångström absorption exponents $(\alpha)$ of 1.0 for traffic $\left(\alpha_{\mathrm{tr}}\right)$, using the wavelength $470 \mathrm{~nm}$, and 2.0 for wood burning $\left(\alpha_{\mathrm{wb}}\right)$ using the wavelength $950 \mathrm{~nm}$, to determine traffic and wood burning contributions. Figure 3 shows the absorption coefficients for wood burning $b_{\text {abs_470wb }}$ (blue) and traffic $b_{\text {abs_950tr }}($ red), both increasing around 17:00-18:00 LT to values lower than $100 \mathrm{Mm}^{-1}$, while $b_{\text {abs }}$ indicates contributions from wood burning and traffic during this event. When the majority of bonfire events are taking place, around 20:00, when $b_{\text {abs }} 470 \mathrm{wb}$ shows the greatest increase, with values reaching $480 \mathrm{Mm}^{-1}$ compared to $150 \mathrm{Mm}^{-1}$ for $b_{\text {abs_}} 950 \mathrm{tr}$.

\subsubsection{PON identification and quantification}

Currently, there is no direct technique to quantify online integrated PON concentrations. However, it is possible to estimate PON concentrations from AMS measurements using the $m / z$ 46:30 ratios (Farmer et al., 2010) as explained in Sect. 2.2.2. This event during Bonfire Night 2014, with high pollutant concentrations provided the opportunity to identify the presence of PON. Inorganic nitrate from $\mathrm{NH}_{4} \mathrm{NO}_{3}$ has been detected at $m / z \quad 46: 30$ ratios between 0.33 and 0.5 (Alfarra et al., 2006) and of 0.37 (Fry et al., 2009), although each instrument-specific ratio is determined during routine calibrations. PON has been identified with $\mathrm{m} / \mathrm{z}$ 46:30 ratios of $0.07-0.10$ (Hao et al., 2014) and 0.17-0.26 (Sato et al., 2010). In this study, $m / z 46: 30$ ratios of $0.11-0.18$ were

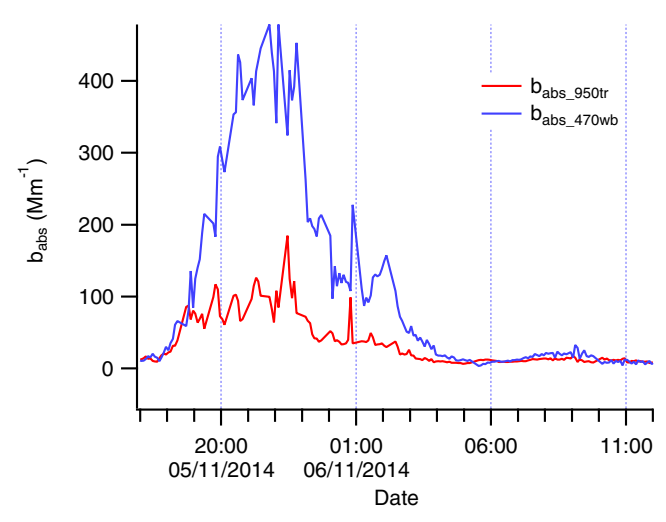

Figure 3. Absorption coefficients for Wood burning (wb) and traffic (tr).

observed during Bonfire Night (Fig. 4), confirming the presence of PON during this event. Figure 4 shows PON concentrations of up to $2.8 \mu \mathrm{g} \mathrm{m}^{-3}$ during Bonfire Night, which are over the detection limit of $0.1 \mu \mathrm{g} \mathrm{m}^{-3}$ reported by Bruns et al. (2010). PON concentrations are considered high compared to previous studies with concentrations between 0.03 and $1.2 \mu \mathrm{g} \mathrm{m}^{-3}$ from a wide variety of sites across Europe (Kiendler-Scharr et al., 2016), while high PON concentrations of $4.2 \mu \mathrm{g} \mathrm{m}^{-3}$ were observed during a biomass burning event in Beijing, China (Zhang et al., 2016).

\subsection{OA source apportionment}

This event with high pollutant concentrations during Bonfire Night gave the opportunity to test the ME-2 factorisation tool 


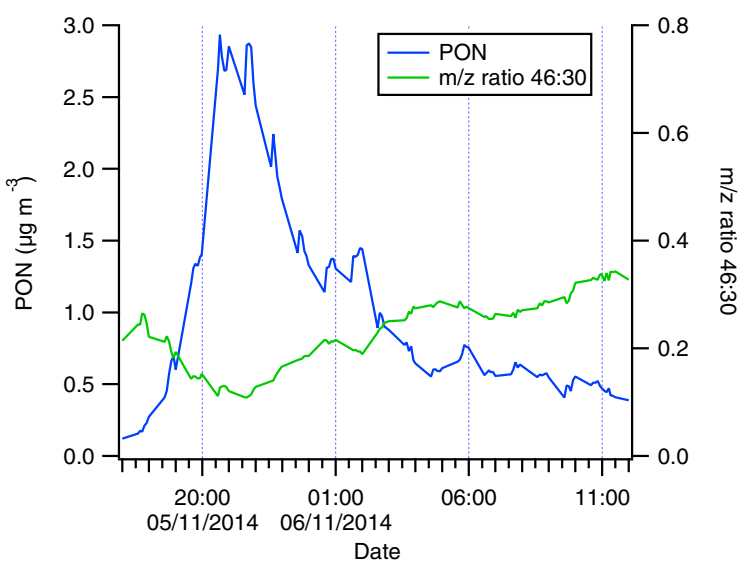

Figure 4. PON concentrations during Bonfire Night. emitted from food cooking activities, is similar to HOA with a higher $m / z 55$ and lower $m / z 57$ (Allan et al., 2010; Slowik et al., 2010; Mohr et al., 2012); LVOOA, identified as a SOA, has a high signal at $m / z 44$ dominated by the $\mathrm{CO}_{2}^{+}$ion $(\mathrm{Ng}$ et al., 2010); sPON_ME2 has a strong signal at $m / z 30$ and it has been identified as secondary as it follows the same trend as LVOOA (Fig. 5a). In the case of the bfo event, six different sources were identified: BBOA, HOA, COA, LVOOA and two factors with peaks at $m / z 30$, which is related to PON (Sun et al., 2012). These two PON factors may have different sources: one may be secondary (sPON_ME2) and the other primary (pPON_ME2), which has a similar trend as BBOA (Fig. 5b). Further details about the nature of pPON_ME2 and sPON_ME2 will be explored in Sect. 4.2.

\section{Discussion}

under these conditions and determine the best way to perform OA source apportionment on a case study event such as this. A number of different approaches for determining the optimal apportionment were tried and the one that yielded the most statistically optimal version was treated as a "best estimate", although it is acknowledged that even this may not be perfect. Indeed, it may not be possible to describe these data completely using the PMF data model. Six different tests were compared: four tests before modifying the fragmentation table and two tests when modifying the fragmentation table to determine a PON source. Test2_ON was the optimal "best estimate" solution, a brief description is given here after being compared to the other tests (Sect. S7.2). From this analysis, Test 2 resulted in being the best way to deconvolve OA sources, with the lowest parameters analysed: residuals, Q/Qexp values and Chi square. After modifying the fragmentation table, Test2_ON still shows a good performance with low parameters (Fig. S6-S8). Refer to Sect. S7 for detailed information about the source apportionment strategy and analysis performed to determine the optimal solution.

Two steps were involved in Test2_ON: in step (a), $\mathrm{PMF} / \mathrm{ME}-2$ were run for the event before and after the Bonfire Night (named as not bonfire event, nbf). In step (b), mass spectra from the solution identified in step (a) were used as TP to analyse the bonfire-only (bfo) event. Finally, both solutions (nbf and bfo) were merged for further analysis. Different OA sources were identified in Test2_ON (Fig. 5), five sources were identified during the nbf event: biomass burning OA (BBOA), hydrocarbon-like OA (HOA), cooking OA (COA), secondary particulate organic oxides of nitrogen (sPON_ME2) and low volatility OA (LVOOA). These sources are identified by characteristic peaks in their respective mass spectra: BBOA, which is generated during the combustion of biomass, has a peak at $m / z$ 60, related to levoglucosan (Alfarra et al., 2007); HOA, related to traffic emissions, presents high signals at $\mathrm{m} / \mathrm{z} 55$ and $\mathrm{m} / \mathrm{z} .57$ typical of aliphatic hydrocarbons (Canagaratna et al., 2004); COA,

\subsection{OA source apportionment during the bfo event}

It is worth noting that while all sources have their characteristic peaks and no apparent mass spectral "mixing" between sources (for example COA with a signal at $\mathrm{m} / \mathrm{z} 60$ ), COA, HOA and LVOOA present high concentrations during Bonfire Night (Fig. 5b). High concentrations of these sources could be expected as these (traffic and cooking activities) increase before and after the main bonfire events and the night represented a very strong inversion (which will trap all pollutants), but given the high concentrations experienced during the event and known variability for biomass burning emissions, the "model error" and thus rotational freedom is likely to be substantial. The result is that these two factors could contain indeterminate contributions from minor variabilities within the biomass burning profile and therefore must be interpreted with caution.

$b_{\text {abs_470wb }}$ has the same source as BBOA, thus the correlation between these two can be used to evaluate the effectiveness of BBOA deconvolution from OA concentrations (Fröhlich et al., 2015; Visser et al., 2015), $r^{2}$ values are calculated and analysed using the following considerations: strong correlation $\left(r^{2} \geq 0.75\right)$, moderate correlation $\left(0.5<r^{2}<0.75\right)$ and low correlation $\left(r^{2} \leq 0.5\right)$. Here $r^{2}$ values are calculated for the bfo event between $b_{\text {abs_470wb }}$ and the two BBOA obtained; BBOA, obtained without modifying the fragmentation table and BBOA_2 obtained after modifying the fragmentation table to identify a PON factor. A slightly higher correlation between $b_{\text {abs_470wb }}$ and BBOA_2 was observed with $r^{2}=0.880$ compared to $r^{2}=0.839$ for $b_{\text {abs }} 470 \mathrm{wb}$ and BBOA. While both have strong correlations from a quantitative point of view, qualitatively there is an improvement in BBOA_2. This improvement in BBOA_2 is explained by the fact that the PON factor may be mixed with BBOA and when both sources are separated, a higher correlation between BBOA_2 and $b_{\text {abs_470wb }}$ is present. There is the possibility that the lower $r^{2}$ between $b_{\text {abs_470wb }}$ and BBOA is due to 

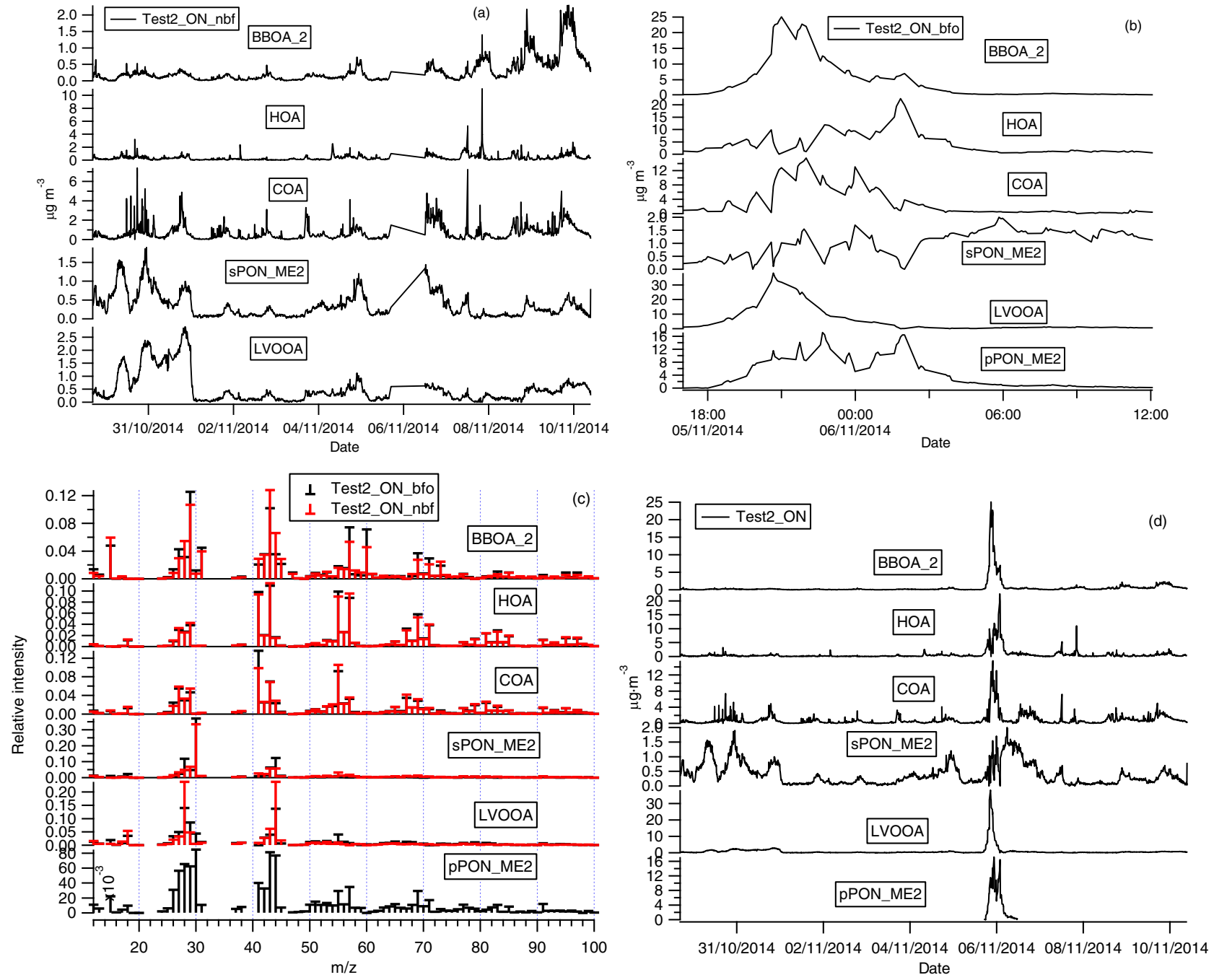

Figure 5. OA sources mass spectra and time series for Test2_ON for bonfire only (bfo) and not bonfire events (nbf). Figure $6 \mathrm{~d}$ shows time series of both events.

having two BBOA factors in Test2. However, an $r^{2}=0.813$ between $b_{\text {abs }} 470 \mathrm{wb}$ and the sum of BBOA + BBOA_1 is still lower than 0.880 .

This shows the importance of performing OA source apportionment using different approaches in order to identify the best way to deconvolve OA sources. PMF and ME-2 source apportionment tools could not completely deconvolve OA sources during the bfo event. However, due to the strong correlation between $b_{\text {abs_470wb }}$ and BBOA_ $2\left(r^{2}=0.880\right)$, we consider that while BBOA_2 might not represent the total OA concentrations from the Bonfire Night event, it does represent the trend of OA emitted from the biomass burning.

\subsection{Primary and secondary PONs}

PON concentrations obtained from the $m / z$ ratios $46: 30$ (blue line in Fig. 6) have a similar trend as BBOA, both increasing at the same time, suggesting a primary origin, but after 22:00 LT, when BBOA concentrations drop, PON concentrations remain present with a slow decrease and maintaining low concentrations when BBOA concentrations were not present anymore. This suggests the hypothesis that there might not be only one type of PON, and it could be divided into primary and secondary organic nitrate as reported in previous studies performed in western Europe (Mohr et al., 2013; Kiendler-Scharr et al., 2016).

Using this working hypothesis, primary and secondary PON concentrations were estimated using the slope between PON and BBOA, calculated from 18:00 to 12:00 LT, a time when the main Bonfire Night event took place (Fig. S10). PON concentrations were multiplied by this slope in order to calculate the primary PON (pPON) and secondary $\mathrm{PON}(\mathrm{sPON})$ and were calculated as $\mathrm{SPON}=\mathrm{PON}-\mathrm{pPON}$. Figure 6 shows the time series of this estimation where 


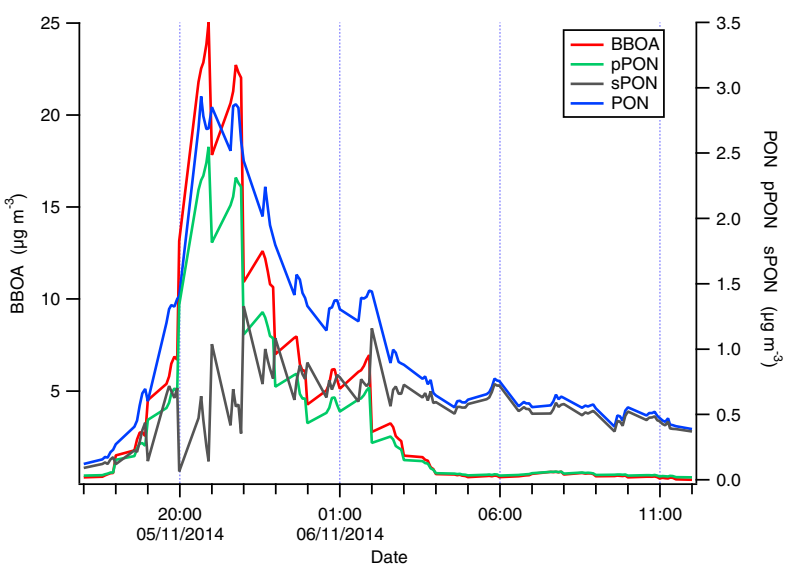

Figure 6. Secondary (sPON) and primary (pPON) organic nitrate time series estimated from PON and BBOA.

pPON reaches $2.5 \mu \mathrm{g} \mathrm{m}^{-3}$ and sPON with concentrations of $0.5 \mu \mathrm{g} \mathrm{m}^{-3}$.

A similar behaviour with two different PON sources was observed in the source apportionment analysis performed in Sect. 3.3, where it was possible to separate two factors with a peak at $m / z$ 30, characteristic of PON. Figure 7 shows that around 02:00LT concentrations of the pPON_ME2 started to decrease (green line) while sPON_ME2 concentrations (grey line) increased. This analysis shows the presence of two different types of PON; pPON_ME2 are primarily emitted along with BBOA concentrations with the further presence of a different PON, considered to be secondary, which increase when primary pollutants start to decrease. Primary and secondary sources of PON have been previously identified from AMS-PMF analyses; Hao et al. (2014) identified PON to be secondary in nature, produced from the interaction between forest and urban emissions, while Zhang et al. (2016) determined PON to be related to primary combustion sources. In this study, it is worth noticing that the increase in SPON_ME2 takes place around 02:00 LT, a period when $\mathrm{NO}$ concentrations started decreasing and CIMSmeasured $\mathrm{N}_{2} \mathrm{O}_{5}$ and $\mathrm{ClNO}_{2}$ started to increase, suggesting that nitrate radical chemistry was occurring (Fig. 8), which is possibly the source of the SPON, although the exact mechanism can only be speculated.

Nitrate chemistry at night is important as nitrate radicals can be the main oxidants in polluted nocturnal environments away from enhanced $\mathrm{NO}$ and can create reservoirs and sinks of $\mathrm{NO}_{x}$. The main $\mathrm{NO}_{x}$ removal at night is via the uptake of dinitrogen pentoxide $\left(\mathrm{N}_{2} \mathrm{O}_{5}\right)$ into aerosols, as at night $\mathrm{N}_{2} \mathrm{O}_{5}$ is formed from $\mathrm{NO}_{3}$ and $\mathrm{NO}_{2}$. In the presence of chloride in the particle phase (e.g. in sea salt particles), $\mathrm{N}_{2} \mathrm{O}_{5}$ reacts to produce nitryl chloride $\left(\mathrm{ClNO}_{2}\right)$. In the morning, following overnight accumulation of $\mathrm{ClNO}_{2}$, photochemical reactions take place to produce $\mathrm{Cl}$ and $\mathrm{NO}_{2} \cdot \mathrm{N}_{2} \mathrm{O}_{5}$ and $\mathrm{ClNO}_{2}$ processing and interactions with nitrate chemistry have been previously studied in the UK (Le Breton et al., 2014a; Bannan et

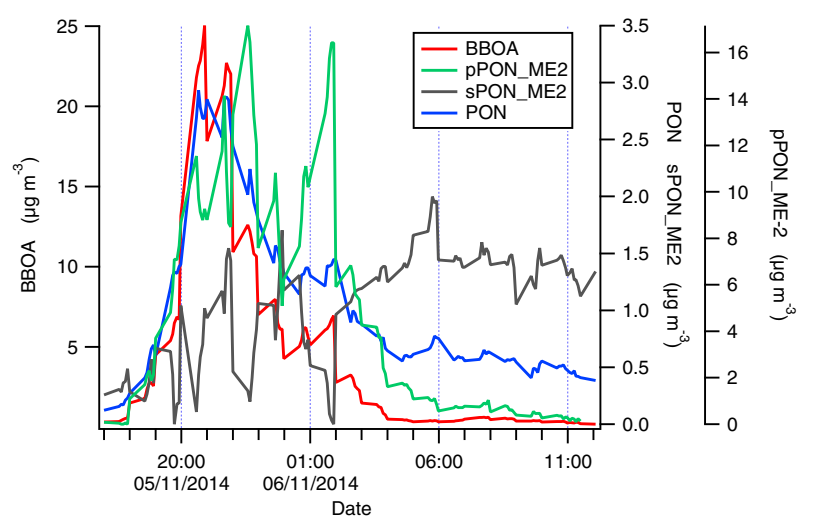

Figure 7. Secondary and primary organic nitrate time series obtained from ME-2 analysis.

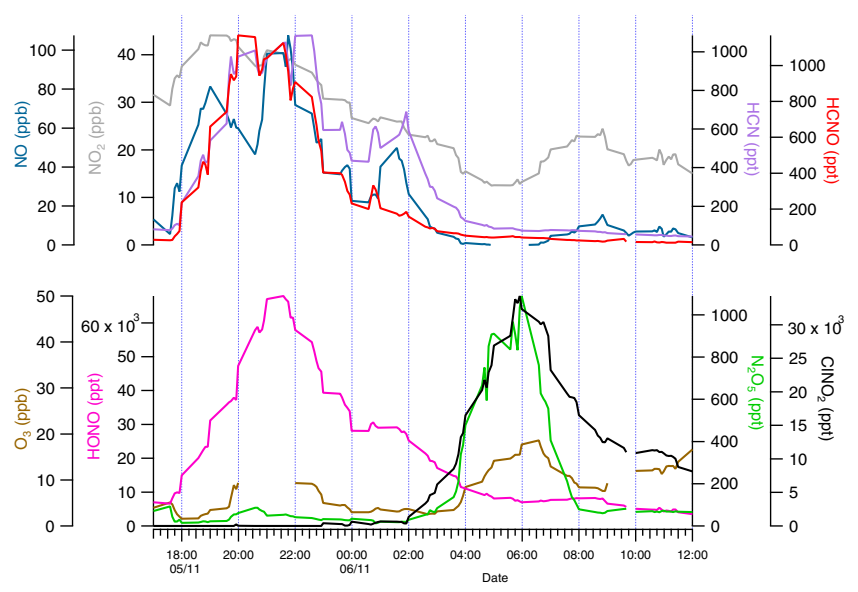

Figure 8. Time series of gases pollutants during Bonfire Night.

al., 2015). Figure 8 shows $\mathrm{N}_{2} \mathrm{O}_{5}, \mathrm{ClNO}_{2}$ and $\mathrm{O}_{3}$ concentrations increasing when $\mathrm{NO}$ and $\mathrm{NO}_{2}$ concentrations decrease. All these processes may facilitate the sPON production at night. $\mathrm{N}_{2} \mathrm{O}_{5}$ concentrations reduce quickly after the sun rises, around 08:00 LT, while $\mathrm{ClNO}_{2}$ concentrations decrease at a slower rate, with the lowest concentrations observed around 13:00 LT. Along with $\mathrm{NO}_{3}$ chemistry, it was possible to observe other nitrogen-containing gases during Bonfire Night using the CIMS such as hydrogen cyanide $(\mathrm{HCN})$ and nitrous acid (HONO), which have been found to be emitted from fires (Le Breton et al., 2013; Wang et al., 2015). High HONO concentrations at night are high the next morning when $\mathrm{HONO}$ reacts to produce $\mathrm{OH}$ and $\mathrm{NO}$, which impacts both the $\mathrm{OH}$ budget and $\mathrm{NO}_{x}$ concentrations early the next morning (Lee et al., 2016).

\subsection{OA factors and CIMS correlations}

Analysing the CIMS measurements and comparing them with the OA factors, it may be possible to identify gas markers that can be used as inputs (target time series) to constrain 
solutions in future ME-2 analyses or as proxies when AMS data are not available. A linear regression was performed between the OA sources determined in Sect. 3.4.1 and CIMS peaks that have been considered positively identified (Priestley et al., in preparation), performing a coefficient of determination $\left(r^{2}\right)$ analysis for the complete dataset (ALL), and the events HSC, LC, bfo and WL. During the event HSC, none of the OA sources showed an $r^{2}$ higher than 0.6. HOA did not have an $r^{2}$ higher than 0.6 with any of the different events analysed. There were no specific markers identified for COA, while COA showed $r^{2}$ values higher than 0.6 for the bfo event, these $r^{2}$ values were also observed with BBOA with even higher values. Table $\mathrm{S} 4$ shows the $r^{2}$ values, higher or equal to 0.4 , obtained in this analysis. It is worth noting that $r^{2}$ values in the ALL event seem to be influenced by the bfo event; this is the case for BBOA, COA and LVOOA, which show similar $r^{2}$ values in both events. Thus, the analysis will only be explained for the individual events (bfo, LC and WL).

As expected, during bfo, $\mathrm{BBOA}$ is the $\mathrm{OA}$ source that shows the highest number of correlations during Bonfire Night. During the bfo episode, strong correlations were observed with BBOA and methacrylic acid $\left(r^{2}=0.92\right)$, acrylic acid (0.90), nitrous acid (0.86), propionic acid, $(0.85)$ and hydrogen cyanide $(0.76)$, which have been previously determined as biomass burning tracers (Veres et al., 2010; Le Breton et al., 2013). Formic acid presented a strong correlation $\left(r^{2}=0.86\right)$ with BBOA during Bonfire Night; however, this value drops to 0.52 for the complete dataset, which suggests formic acid during Bonfire Night is mainly primary, while formic acid concentrations measured for the whole dataset may be related to primary and secondary sources. This agrees with Le Breton et al. (2014b) who explored both primary and secondary origins of formic acid.

During the bfo event, LVOOA did not show a characteristic gas marker, as all the $r^{2}$ values were also observed with BBOA. This suggests two hypotheses: that the LVOOA was mixed with BBOA, in the form of humic-like material (Paglione et al., 2014), which cannot be differentiated from secondary OA in the mass spectra (Fig. 5c); or it could also be that secondary LVOOA may actually be present at the same time as BBOA concentrations, as during high relative humidity and low temperatures, enhanced partitioning of semi-volatile material to the particle phase occurs, where subsequent oxidation and oligomerisation may occur. Moreover, due to the high aerosol concentration present during Bonfire Night, there is a greater surface available for gases to be condensed and more particulate bulk to absorb into, thus it could be speculated that there would be high secondary aerosol concentrations. However, this is deemed unlikely as there may be little gas phase oxidation occurring in the presence of such high NO concentrations, which will remove ozone and nitrate radicals, the main source of oxidants at night.
During the bfo event, pPON_ME2 showed high $r^{2}$ values with carbon monoxide $(0.78)$ and hydrogen cyanide $(0.77)$ and moderate correlations with methylformamide $(0.65)$ and dimethylformamide (0.63), all of which are typical primary pollutants related to combustion processes (Borduas et al., 2015 , and references therein). sPON_ME2 showed moderate correlations with $\mathrm{ClNO}_{2}(0.52)$ and $\mathrm{ClNO}_{3}$ (0.53). Moderate $r^{2}$ values were also observed during the LC episode between $\mathrm{ClNO}_{2}-\mathrm{ClNO}_{3}$ and LVOOA (0.67-0.66) and sPON (0.74-0.69) proving their secondary origin. $\mathrm{Cl}_{2}$, which has previously been identified to be related to both primary and secondary sources (Faxon et al., 2015), shows low correlations with pPON_ME2 (0.44) during the bfo event and sPON_ME2 (0.55) during the LC event.

\subsection{PON and its relationship with $b_{\text {abs_470wb }}$ and BBOA}

Organic oxides of nitrogen, originating from biomass burning, have been previously found to absorb light near the UV region (Jacobson, 1999; Flowers et al., 2010; Mohr et al., 2013). However, there is still a question of whether this absorption is due to primary or secondary PON. Here, the relationship between $b_{\text {abs_ } 470 \mathrm{wb}}$, PON and BBOA will be analysed to determine if PONs absorb at $470 \mathrm{~nm}$, which would interfere with Aethalometer measurements.

In order to quantitatively determine any contribution from PON to the Aethalometer data products, a multilinear regression (MLR) analysis was performed on the complete dataset (ALL), and the events HSC, LC, bfo and WL (Table 1). This analysis was done in three ways: a multilinear regression (MLR1) with BBOA from OA source apportionment without modifying the fragmentation table and PON from $m / z$ 46:30 analysis; a multilinear regression (MLR2) with BBOA_2 from OA source apportionment after modifying the fragmentation table and PON from 46:30 analysis; and a multilinear regression (MLR3) with BBOA_2 and PON sources from OA source apportionment after modifying the fragmentation table. The following bilinear regression was used:

$b_{\text {abs_ } 470 \mathrm{wb}}=A+B \cdot x 1+C \cdot x 2$,

with $x 1=$ BBOA and $x 2=$ PON for MLR $1 ; x 1=$ BBOA $\_2$ and $x 2=$ PON for MLR2; $x 1=$ BBOA_2 and $x 2=$ sPON_ME2 for MLR3. Additionally, a trilinear regression was performed to $* \mathrm{HSC}$ and $*$ bfo with $x 3=$ LVOOA in $* \mathrm{HSC}$ and $x 3=$ pPON in $*$ bfo. $A$ is the origin and the partial slopes $B, C$ and $D$ represent the contribution of $x 1$, $x 2$ and $x 3$ to $b_{\text {abs }} 470 \mathrm{wb}$, respectively.

As used in previous studies (Elser et al., 2016; ReyesVillegas et al., 2016), multilinear regression analysis allows for the relationship of one parameter between two or more variables to be determined. Here we are analysing the partial slopes and origin to determine the correlation of $b_{\text {abs_-470wb }}$ with the other variables. Table 1 shows the MLR outputs where; $A$ represents the background, $B, C$ and $D$ represent 
Table 1. Multilinear (MLR) and linear regression analysis between $b_{\text {abs_470wb }}$ and OAs.

\begin{tabular}{|c|c|c|c|c|c|c|c|c|}
\hline & & & ALL & \multicolumn{2}{|c|}{ HSC } & $\mathrm{LC}$ & bfo & WL \\
\hline \multirow[t]{5}{*}{ MLR 1} & $A$ & background & 0.000 & \multicolumn{2}{|c|}{4.555} & 1.004 & 0.000 & 1.293 \\
\hline & $B$ & $b_{\mathrm{abs}}: \mathrm{BBOA}$ & 14.340 & \multicolumn{2}{|c|}{3.547} & 18.284 & 11.926 & 10.318 \\
\hline & $C$ & $b_{\mathrm{abs}}: \mathrm{PON}$ & 54.495 & \multicolumn{2}{|c|}{9.212} & 12.046 & 73.115 & 21.724 \\
\hline & & $B / C$ & 0.263 & \multicolumn{2}{|c|}{0.385} & 1.518 & 0.163 & 0.475 \\
\hline & & $r^{2} \_$MLR1 & 0.912 & \multicolumn{2}{|c|}{0.064} & 0.364 & 0.898 & 0.760 \\
\hline \multirow[t]{2}{*}{ Linear 1} & $r^{2}$ & $b_{\mathrm{abs}}: \mathrm{BBOA}$ & 0.861 & \multicolumn{2}{|c|}{0.043} & 0.358 & 0.839 & 0.739 \\
\hline & & $b_{\mathrm{abs}}: \mathrm{PON}$ & 0.819 & \multicolumn{2}{|c|}{0.060} & 0.275 & 0.897 & 0.311 \\
\hline \multirow[t]{5}{*}{ MLR 2} & $A$ & background & 0.000 & \multicolumn{2}{|c|}{2.527} & 0.753 & 0.000 & 0.079 \\
\hline & $B$ & $b_{\mathrm{abs}}:$ BBOA_2 & 15.653 & \multicolumn{2}{|c|}{27.288} & 26.481 & 14.319 & 10.018 \\
\hline & $C$ & $b_{\mathrm{abs}}: \mathrm{PON}$ & 42.840 & \multicolumn{2}{|c|}{0.000} & 1.200 & 54.353 & 18.982 \\
\hline & & $B / C$ & 0.365 & \multicolumn{2}{|c|}{$* * *$} & 22.060 & 0.263 & 0.528 \\
\hline & & $r^{2} \_$MLR2 & 0.922 & \multicolumn{2}{|c|}{0.392} & 0.480 & 0.902 & 0.804 \\
\hline \multirow[t]{3}{*}{ Linear 2} & $r^{2}$ & $b_{\mathrm{abs}}:$ BBOA_2 & 0.894 & \multirow{2}{*}{\multicolumn{2}{|c|}{$\begin{array}{l}0.392 \\
0.060\end{array}$}} & 0.480 & 0.880 & 0.788 \\
\hline & & $b_{\mathrm{abs}}: \mathrm{PON}$ & 0.819 & & & 0.275 & 0.897 & 0.311 \\
\hline & & & ALL & HSC & *HSC & $\mathrm{LC}$ & *bfo & WL \\
\hline \multirow[t]{7}{*}{ MLR 3} & $A$ & background & 0.000 & 2.527 & 1.649 & 0.763 & 6.093 & 0 \\
\hline & $B$ & $b_{\mathrm{abs}}:$ BBOA_2 & 21.545 & 27.288 & 22.764 & 26.668 & 16.657 & 8.577 \\
\hline & $C$ & $b_{\text {abs }}:$ sPON_ME2 & 3.926 & 0.000 & 0.000 & 0.191 & 0.000 & 9.017 \\
\hline & $D$ & $D$ & & & 1.138 & & 7.357 & \\
\hline & & $B / C$ & 5.488 & $* * *$ & $* * *$ & $* * *$ & $* * *$ & 0.951 \\
\hline & & $B / D$ & & & 20.005 & & 2.264 & \\
\hline & & $r^{2}-$ MLR3 & 0.896 & 0.392 & 0.418 & 0.480 & 0.910 & 0.803 \\
\hline \multirow[t]{3}{*}{ Linear 3} & $r^{2}$ & $b_{\mathrm{abs}}:$ BBOA_2 & 0.894 & 0.392 & 0.392 & 0.480 & 0.880 & 0.788 \\
\hline & & $b_{\mathrm{abs}}: \mathrm{sPON}$ _ME2 & 0.024 & 0.000 & 0.000 & 0.273 & 0.188 & 0.647 \\
\hline & & $b_{\mathrm{abs}}: \mathrm{D}$ & & & 0.225 & & 0.633 & \\
\hline
\end{tabular}

$\mathrm{ALL}=$ complete dataset; $\mathrm{HSC}=$ episode with high secondary concentrations ( 30 October to 1 November); $\mathrm{LC}=$ episode with low concentrations ( $1-3$ November); bfo = episode with bonfire-only concentrations ( 5 November 17:00 LT to

6 November 12:00 LT); WL = Episode with winter-like characteristics (8-10 November). PON is the particulate organic nitrate estimate from $46: 30$ ratios. *Trilinear regression was performed as in *bfo analysis there were two PON factors from ME-2 analysis; pPON_ME2 and sPON_ME2, with the slope $D=b_{\text {abs }}$ :pPON and $r^{2} D$ is the $r^{2}$ between $b_{\text {abs }}$ :pPON. In *HSC analysis; BBOA, sPON and LVOOA were used, with the slope $D=b_{\mathrm{abs}}:$ LVOOA and $r^{2} \_D$ is the $r^{2}$ between $b_{\mathrm{abs}}:$ LVOOA

the partial slope between $b_{\text {abs } 470 \mathrm{wb}}$ and the respective OA. $B / C$ represents the ratio between $B$ and $C$ partial slopes, with the following considerations: if $B / C<1$, then there is a higher contribution of PON to $b_{a b s_{-} 470 w b}$; if $B / C>1$, then there is a higher contribution of BBOA to $b_{\text {abs_- } 470 \mathrm{wb}}$. Looking at the coefficient of determination of the multilinear regression $\left(r^{2}{ }_{2}\right.$ MLR) for the three MLR analyses, it is possible to observe that, on the one hand, HSC and LC events present low $r^{2}$ _MLR values ranging from 0.064 and 0.480 ; On the other hand, bfo and WL events have strong correlations with values between 0.760 and 0.910 , which shows that when high primary OA emissions are present a strong correlation between $b_{\text {abs_470wb }}$ and BBOA and PON is observed.

These high $r^{2}$ values, particularly during the bfo event which presented the highest $r^{2}(0.910)$, are consistent with previous studies that found organic nitrates to absorb at short wavelengths; Mohr et al. (2013) identified correlation values of 0.65 between nitrophenols and $b_{\text {abs_370wb }}$. Teich et al. (2017), in a recent study from offline filters, determined nitrated aerosol concentrations with further analysis of the light absorption of aqueous filter extracts $\left(b_{\text {abs_370 }}\right)$ and identified $r^{2}$ values between $b_{\text {abs_370 }}$ and nitrated aerosol concentrations of 0.67 to 0.74 depending on acidic or alkaline conditions, respectively.

In MLR3, it is possible to observe that, during the bfo event, the main contribution to $b_{\mathrm{abs}} 470 \mathrm{wb}$ is attributed to both BBOA_2 (16.657) and pPON_ME2 (7.357), while $b_{\text {abs }}$ :sPON_ME-2 values were zero, with an optimum $r^{2}$ of 0.910. This lack of correlation between $b_{\mathrm{abs}}$ and sPON is observed in the linear regression $b_{\text {abs }}:$ SPON_ME2 with an $r^{2}$ of 0.188 . These results show that while there is evidence of pPON_ME2 absorbing at $470 \mathrm{~nm}$, with a partial slope of 16.657, sPON_ME2 did not show to be absorbing at $470 \mathrm{~nm}$. The implication of the background not going to zero (6.093) is that there is still an unexplained contribution to the absorption at $470 \mathrm{~nm}$, unrelated to sPON_ME2. 
In order to further explore the possibility of sPON_ME2 absorbing at $470 \mathrm{~nm}$, the HSC event was analysed, where sPON_ME2 was shown to be non-absorbing at $470 \mathrm{~nm}$ with a partial slope of zero. BBOA_2 had a partial slope of 27.288 and background a value of 2.527. This background value suggests there is another component related to $b_{\text {abs_470wb }}$ that is not sPON. Thus, a trilinear regression was performed to *HSC between $b_{\text {abs_470wb }}$ and BBOA_2, sPON and LVOOA. Here, the background value drops to 1.649 , sPON partial slope is zero and LVOOA presents a partial slope of 1.138. These results confirm that sPON do not absorb light at $470 \mathrm{~nm}$ while LVOOA, or at least part of the components of LVOOA, do absorb at $470 \mathrm{~nm}$ during the HSC event and pPON_ME2 during the bfo event.

These results agree with previous studies that found biomass burning BBOA to contain important concentrations of light absorbing $\mathrm{BrC}$ and that certain types of $\mathrm{SOA}$ are effective absorbers near UV light (Bones et al., 2010; Saleh et al., 2014; Washenfelder et al., 2015). The fact that pPON_ME2 and LVOOA were shown to be absorbing light at a short wavelength $(470 \mathrm{~nm})$ will have a direct impact on Aethalometer model studies; while pPON_ME2 could be considered a component of the wood burning aerosol apportioned using the Aethalometer, it may be that there is an interference from other forms of $\mathrm{BrC}$ in SOA. However, this work would suggest that SPON specifically does not contribute to the latter, so a different component of LVOOA would have to be responsible. As well as this Aethalometer interpretation, it is also worth mentioning that these findings may have implications for studies on the radiative properties of the atmosphere, as $\mathrm{BrC}$ is also thought to affect climate (Jacobson, 2014).

\section{Conclusions}

In order to better understand the aerosol chemical composition and variation in source contribution during periods of nocturnal pollution, online measurements of gases and aerosols were made in ambient air between 29 October and 10 November 2014 at the University of Manchester, with detailed analysis of the special high pollutant concentrations during Bonfire Night celebrations on 5 November. High aerosol concentrations were observed during the Bonfire Night event with $115 \mu \mathrm{g} \mathrm{m}^{-3}$ of $\mathrm{PM}_{1}$. Important nitrogen chemistry was present with high $\mathrm{HCN}, \mathrm{HCNO}$ and $\mathrm{HONO}$ concentrations primarily emitted with the further presence of $\mathrm{N}_{2} \mathrm{O}_{5}$ and $\mathrm{ClNO}_{2}$ concentrations from nocturnal nitrate chemistry taking place after $\mathrm{NO}_{x}$ concentrations decreased.

OA source apportionment was performed using the ME2 factorisation tool. The particular high pollutant concentrations together with the complex mix of emissions did not allow the running of ME-2 for the complete dataset, thus the dataset was divided into different events. The best way to perform source apportionment was found to be to (a) anal- yse the event before and after Bonfire Night using BBOA, HOA and COA from a previous study in Paris as TP, and (b) conduct a further ME-2 analysis of the Bonfire Night event using BBOA, HOA and COA mass spectra from (a) as TP. Moreover, a slight improvement in the source apportionment was observed after modifying the fragmentation table in order to identify PON sources, increasing the $r^{2}$ value from linear regressions between $b_{\text {abs_470wb }}$ (absorption coefficient of wood burning at $470 \mathrm{~nm}$ ) and BBOA from 0.839 to 0.880 . PMF and ME-2 source apportionment tools could not completely deconvolve $\mathrm{OA}$ sources during the bfo event as LVOOA, COA and HOA may be mixed with BBOA concentrations. However, due to the strong correlation between $b_{\text {abs_470wb }}$ and BBOA $\left(r^{2}=0.880\right)$ we consider that while BBOA might not represent the total OA concentrations from the Bonfire Night event, it does represent the trend of OA emitted from the biomass burning.

The combination of CIMS measurements and OA sources determined from AMS measurements provided important information about gas tracers to be used as inputs (target time series) to improve future ME-2 analyses, particularly gases correlating with BBOA, LVOOA and sPON. However, the use of these species as target time series should be used with care as their time variation is greatly affected by meteorological conditions.

The presence of two classes of PON, secondary (sPON_ME2) and primary (pPON_ME2), was identified both from looking at the BBOA:PON relationship and from the ME-2 analysis after modifying the fragmentation table. It is clear that, during Bonfire Night, pPON_ME2 concentrations increased when $\mathrm{BBOA}$ concentrations are present and sPON_ME2 concentrations started evolving when the primary concentrations decreased.

It was determined that pPON_ME2 absorbed light at a wavelength of $470 \mathrm{~nm}$ during Bonfire Night, where the multilinear regression performed between $b_{\text {abs_ } 470 \mathrm{wb}}$, BBOA and pPON_ME2 showed a strong $r^{2}$ of 0.910 , while sPON_ME2 did not contribute to light absorption at $470 \mathrm{~nm}$. During the HSC episode, LVOOA showed a partial slope of 1.138 in the multilinear regression and an $r^{2}$ from linear regression with $b_{\text {abs_470wb }}$ of 0.225 , implying secondary LVOOA (associated with SOA) may be absorbing at $470 \mathrm{~nm}$ and sPON_ME2 was not absorbing at this wavelength. These results will help us to understand the mechanistic contributions to UV absorption in the Aethalometer and will have direct implications for source apportionment studies, which may need to be corrected for SOA interferences near the UV region.

Data availability. The data are available upon request from the corresponding author and from James Allan (james.allan@manchester.ac.uk). 
Appendix A: Source apportionment solution without modifying the fragmentation table
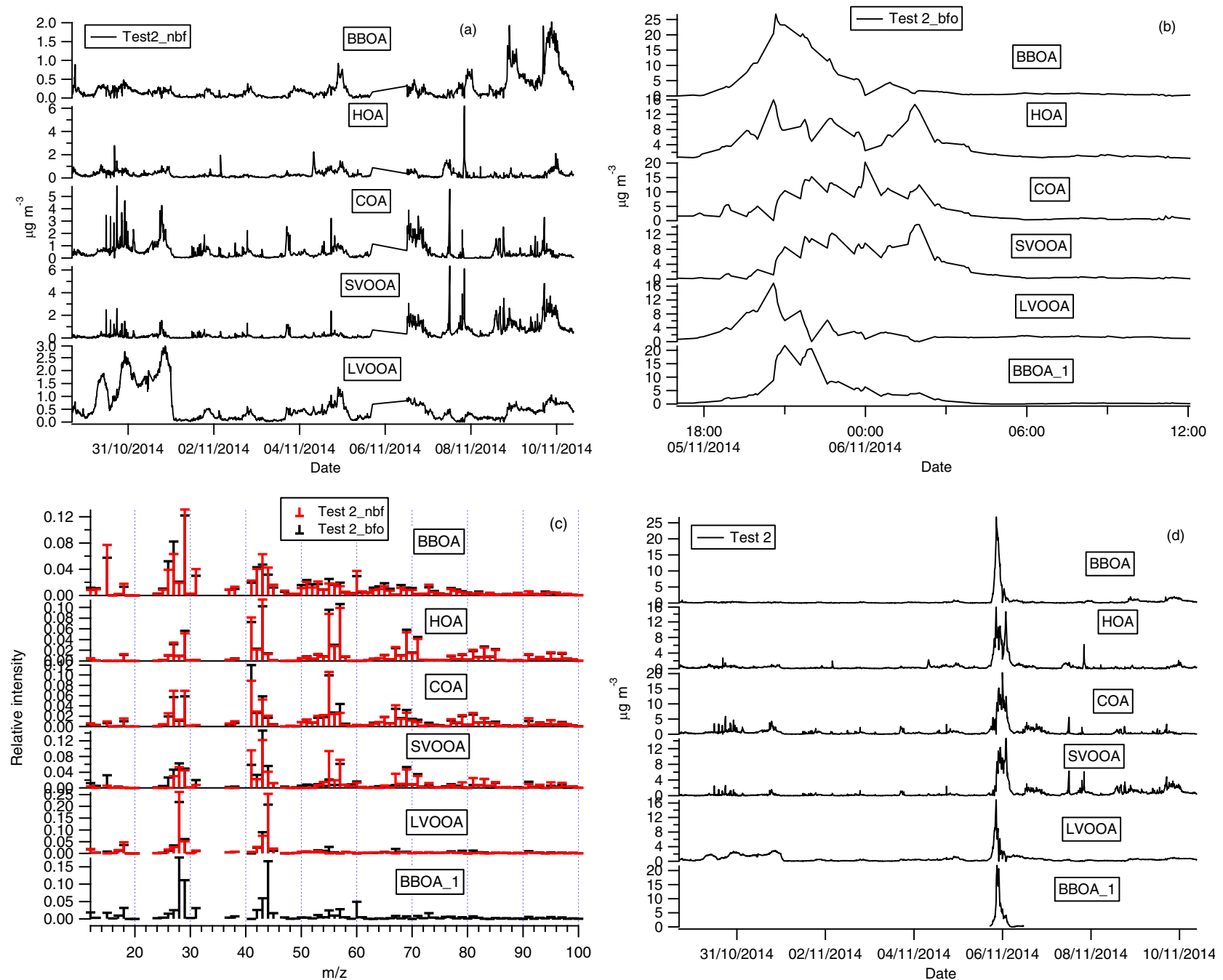

Figure A1. OA sources mass spectra and time series for Test2.

Figure A1 presents results obtained with Test2. Figure A1c shows mass spectra of the two chosen solutions: five sources were identified during the nbf period: BBOA, HOA, COA, SVOOA and LVOOA. In the case of the bfo period, six different sources were identified: BBOA; $\mathrm{HOA}$; $\mathrm{COA}$; factor4, which seems to be a mixed factor with a peak at $\mathrm{m} / z 43$ (characteristic of SVOOA) and peaks at $m / z 55$ and $m / z 57$ (characteristic of HOA); LVOOA and BBOA_1. BBOA_1 source appears to be mixed between LVOOA (peaks at $m / z 28$ and $m / z$ 44) and BBOA (peak at $m / z$ 60). We can see here, that while Test 2 resulted to be the best way to deconvolve OA sources compared to tests 1, 3 and 4, it still shows mixing with SVOOA, LVOOA and BBOA_1. A situation that improved when doing OA source apportionment after modifying the fragmentation table in Test2_ON. 


\section{Appendix B: Symbols and description of main parameters used}

Symbol Description

Events

\begin{tabular}{|c|c|}
\hline $\begin{array}{l}\text { bfo } \\
\text { nbf }\end{array}$ & $\begin{array}{l}\text { bonfire-only event ( } 5 \text { November 05:00-17:00 LT to } 6 \text { November 12:00 LT) } \\
\text { not bonfire (before and after bonfire night) }\end{array}$ \\
\hline HSC & high secondary concentrations ( 30 October to 1 November) \\
\hline $\mathrm{LC}$ & low concentrations ( $1-3$ November) \\
\hline WL & winter-like (8-10 November) \\
\hline
\end{tabular}

\begin{tabular}{|c|c|}
\hline$\alpha$ & Ångström absorption exponent \\
\hline$\alpha_{\mathrm{tr}}$ & Ångström absorption exponent for traffic \\
\hline$\alpha_{\mathrm{wb}}$ & Ångström absorption exponent for wood burning \\
\hline ATN & attenuation \\
\hline $\mathrm{BC}$ & black carbon $\left(\mu \mathrm{g} \mathrm{m}^{-3}\right)$ \\
\hline$b_{\mathrm{abs}}$ & absorption coefficient $\left(\mathrm{Mm}^{-1}\right)$ \\
\hline$b_{\text {abs_470 }}$ & absorption coefficient at $470 \mathrm{~nm}\left(\mathrm{Mm}^{-1}\right)$ \\
\hline$b_{\text {abs_} \_950}$ & absorption coefficient at $950 \mathrm{~nm}\left(\mathrm{Mm}^{-1}\right)$ \\
\hline$\sigma_{\mathrm{ATN}}$ & attenuation cross section $\left(\mathrm{m}^{2} \mathrm{~g}^{-1}\right)$ \\
\hline$\lambda$ & wavelength $(\mathrm{nm})$ \\
\hline$b_{\mathrm{ATN}}$ & uncorrected absorption coefficient $\left(\mathrm{Mm}^{-1}\right)$ \\
\hline$b_{\mathrm{abs}}$ & corrected absorption coefficient $\left(\mathrm{Mm}^{-1}\right)$ \\
\hline$C$ & multiple scattering correction constant \\
\hline$R$ & filter loading correction \\
\hline$f$ & shadowing factor \\
\hline
\end{tabular}

BBOA biomass burning organic OA obtained without modifying the fragmentation table

BBOA_1 second biomass burning organic OA obtained without modifying the fragmentation table

BBOA_2 biomass burning organic OA obtained after modifying the fragmentation table

HOA hydrocarbon-like OA

COA cooking OA

SVOOA semi-volatile OA

LVOOA low volatility OA

PON particulate organic oxides of nitrogen, calculated with $46: 30$ ratios.

pPON primary particulate organic oxides of nitrogen, estimated using the slope between PON and BBOA

sPON secondary particulate organic oxides of nitrogen, $s P O N=P O N-p P O N$

pPON_ME2 primary particulate organic oxides of nitrogen, calculated from ME-2 analysis

sPON_ME2 secondary particulate organic oxides of nitrogen, calculated from ME-2 analysis 


\section{The Supplement related to this article is available online at https://doi.org/10.5194/acp-18-4093-2018-supplement.}

Author contributions. ERV, MF, HC, CP, JA designed the project; ERV, YCT, SH, TB, MLB, PW, AB, operated, calibrated and performed QA of instrument measurements; ERV and MP performed the data analysis; ERV, HC and JA wrote the paper.

Competing interests. The authors declare that they have no conflict of interest.

Acknowledgements. This work was supported through the UK Natural Environment Research Council (NERC) through the Com-Part (grant ref: NE/K014838/1). Ernesto Reyes-Villegas is supported by a studentship by the National Council of Science and Technology-Mexico (CONACYT) under registry number 217687.

Edited by: Astrid Kiendler-Scharr

Reviewed by: two anonymous referees

\section{References}

Ainsworth, W. H.: Guy fawkes; or, the gunpowder treason, Nottingham Society, London, UK, 1850.

Alfarra, M. R., Paulsen, D., Gysel, M., Garforth, A. A., Dommen, J., Prévôt, A. S. H., Worsnop, D. R., Baltensperger, U., and Coe, H.: A mass spectrometric study of secondary organic aerosols formed from the photooxidation of anthropogenic and biogenic precursors in a reaction chamber, Atmos. Chem. Phys., 6, 52795293, https://doi.org/10.5194/acp-6-5279-2006, 2006.

Alfarra, M. R., Prévôt, A. S. H., Szidat, S., Sandradewi, J., Weimer, S., Lanz, V. A., Schreiber, D., Mohr, M., and Baltensperger, U.: Identification of the mass spectral signature of organic aerosols from wood burning emissions, Environ. Sci. Technol., 41, 57705777, https://doi.org/10.1021/Es062289b, 2007.

Allan, J. D., Delia, A. E., Coe, H., Bower, K. N., Alfarra, M. R., Jimenez, J. L., Middlebrook, A. M., Drewnick, F., Onasch, T. B., Canagaratna, M. R., Jayne, J. T., and Worsnop, D. R.: A generalised method for the extraction of chemically resolved mass spectra from aerodyne aerosol mass spectrometer data, J. Aerosol Sci., 35, 909-922, https://doi.org/10.1016/j.jaerosci.2004.02.007, 2004.

Allan, J. D., Alfarra, M. R., Bower, K. N., Coe, H., Jayne, J. T., Worsnop, D. R., Aalto, P. P., Kulmala, M., Hyötyläinen, T., Cavalli, F., and Laaksonen, A.: Size and composition measurements of background aerosol and new particle growth in a Finnish forest during QUEST 2 using an Aerodyne Aerosol Mass Spectrometer, Atmos. Chem. Phys., 6, 315-327, https://doi.org/10.5194/acp-6315-2006, 2006.

Allan, J. D., Williams, P. I., Morgan, W. T., Martin, C. L., Flynn, M. J., Lee, J., Nemitz, E., Phillips, G. J., Gallagher, M. W., and Coe, H.: Contributions from transport, solid fuel burning and cooking to primary organic aerosols in two UK cities, Atmos.
Chem. Phys., 10, 647-668, https://doi.org/10.5194/acp-10-6472010, 2010.

Bannan, T. J., Booth, A. M., Bacak, A., Muller, J. B. A., Leather, K. E., Le Breton, M., Jones, B., Young, D., Coe, H., Allan, J., Visser, S., Slowik, J. G., Furger, M., Prevot, A. S. H., Lee, J., Dunmore, R. E., Hopkins, J. R., Hamilton, J. F., Lewis, A. C., Whalley, L. K., Sharp, T., Stone, D., Heard, D. E., Fleming, Z. L., Leigh, R., Shallcross, D. E., and Percival, C. J.: The first uk measurements of nitryl chloride using a chemical ionization mass spectrometer in central london in the summer of 2012, and an investigation of the role of cl atom oxidation, J. Geophys. Res.-Atmos., 120, 5638-5657, https://doi.org/10.1002/2014JD022629, 2015.

Bones, D. L., Henricksen, D. K., Mang, S. A., Gonsior, M., Bateman, A. P., Nguyen, T. B., Cooper, W. J., and Nizkorodov, S. A.: Appearance of strong absorbers and fluorophores in limonene-o3 secondary organic aerosol due to nh4+-mediated chemical aging over long time scales, J. Geophys. Res.-Atmos., 115, D05203, https://doi.org/10.1029/2009jd012864, 2010.

Borduas, N., da Silva, G., Murphy, J. G., and Abbatt, J. P. D.: Experimental and theoretical understanding of the gas phase oxidation of atmospheric amides with oh radicals: Kinetics, products, and mechanisms, J. Phys. Chem. A, 119, 4298-4308, https://doi.org/10.1021/jp503759f, 2015.

Bruns, E. A., Perraud, V., Zelenyuk, A., Ezell, M. J., Johnson, S. N., Yu, Y., Imre, D., Finlayson-Pitts, B. J., and Alexander, M. L.: Comparison of ftir and particle mass spectrometry for the measurement of particulate organic nitrates, Environ. Sci. Technol., 44, 1056-1061, https://doi.org/10.1021/es9029864, 2010.

Canagaratna, M. R., Jayne, J. T., Ghertner, D. A., Herndon, S., Shi, Q., Jimenez, J. L., Silva, P. J., Williams, P., Lanni, T., Drewnick, F., Demerjian, K. L., Kolb, C. E., and Worsnop, D. R.: Chase studies of particulate emissions from in-use new york city vehicles, Aerosol Sci. Tech., 38, 555-573, https://doi.org/10.1080/02786820490465504, 2004.

Canonaco, F., Crippa, M., Slowik, J. G., Baltensperger, U., and Prévôt, A. S. H.: SoFi, an IGOR-based interface for the efficient use of the generalized multilinear engine (ME2) for the source apportionment: ME-2 application to aerosol mass spectrometer data, Atmos. Meas. Tech., 6, 3649-3661, https://doi.org/10.5194/amt-6-3649-2013, 2013.

Chakraborty, A., Gupta, T., and Tripathi, S. N.: Chemical composition and characteristics of ambient aerosols and rainwater residues during indian summer monsoon: Insight from aerosol mass spectrometry, Atmos. Environ., 136, 144-155, https://doi.org/10.1016/j.atmosenv.2016.04.024, 2016.

Clark, H.: New directions. Light blue touch paper and retire, Atmos. Environ., 31, 2893-2894, https://doi.org/10.1016/s13522310(97)88278-7, 1997.

Colbeck, I. and Chung, M.-C.: Ambient aerosol concentrations at a site in se england during bonfire night 1995, J. Aerosol Sci., 27, Supplement 1, S449-S450, https://doi.org/10.1016/00218502(96)00297-2, 1996.

Crilley, L. R., Bloss, W. J., Yin, J., Beddows, D. C. S., Harrison, R. M., Allan, J. D., Young, D. E., Flynn, M., Williams, P., Zotter, P., Prevot, A. S. H., Heal, M. R., Barlow, J. F., Halios, C. H., Lee, J. D., Szidat, S., and Mohr, C.: Sources and contributions of wood smoke during winter in London: assessing local and regional influences, Atmos. Chem. Phys., 15, 3149-3171, https://doi.org/10.5194/acp-15-3149-2015, 2015. 
Crippa, M., DeCarlo, P. F., Slowik, J. G., Mohr, C., Heringa, M. F., Chirico, R., Poulain, L., Freutel, F., Sciare, J., Cozic, J., Di Marco, C. F., Elsasser, M., Nicolas, J. B., Marchand, N., Abidi, E., Wiedensohler, A., Drewnick, F., Schneider, J., Borrmann, S., Nemitz, E., Zimmermann, R., Jaffrezo, J.-L., Prévôt, A. S. H., and Baltensperger, U.: Wintertime aerosol chemical composition and source apportionment of the organic fraction in the metropolitan area of Paris, Atmos. Chem. Phys., 13, 961-981, https://doi.org/10.5194/acp-13-961-2013, 2013.

Crippa, M., Canonaco, F., Lanz, V. A., Äijälä, M., Allan, J. D., Carbone, S., Capes, G., Ceburnis, D., Dall'Osto, M., Day, D. A., DeCarlo, P. F., Ehn, M., Eriksson, A., Freney, E., Hildebrandt Ruiz, L., Hillamo, R., Jimenez, J. L., Junninen, H., Kiendler-Scharr, A., Kortelainen, A.-M., Kulmala, M., Laaksonen, A., Mensah, A. A., Mohr, C., Nemitz, E., O’Dowd, C., Ovadnevaite, J., Pandis, S. N., Petäjä, T., Poulain, L., Saarikoski, S., Sellegri, K., Swietlicki, E., Tiitta, P., Worsnop, D. R., Baltensperger, U., and Prévôt, A. S. H.: Organic aerosol components derived from 25 AMS data sets across Europe using a consistent ME-2 based source apportionment approach, Atmos. Chem. Phys., 14, 61596176, https://doi.org/10.5194/acp-14-6159-2014, 2014.

Day, D. A., Liu, S., Russell, L. M., and Ziemann, P. J.: Organonitrate group concentrations in submicron particles with high nitrate and organic fractions in coastal southern california, Atmos. Environ., 44, 1970-1979, https://doi.org/10.1016/j.atmosenv.2010.02.045, 2010.

Drewnick, F., Hings, S. S., DeCarlo, P., Jayne, J. T., Gonin, M., Fuhrer, K., Weimer, S., Jimenez, J. L., Demerjian, K. L., Borrmann, S., and Worsnop, D. R.: A new time-of-flight aerosol mass spectrometer (tof-ams) - instrument description and first field deployment, Aerosol Sci. Tech., 39, 637-658, https://doi.org/10.1080/02786820500182040, 2005.

Drewnick, F., Hings, S. S., Curtius, J., Eerdekens, G., and Williams, J.: Measurement of fine particulate and gasphase species during the new year's fireworks 2005 in mainz, germany, Atmos. Environ., 40, 4316-4327, https://doi.org/10.1016/j.atmosenv.2006.03.040, 2006.

Drewnick, F., Diesch, J.-M., Faber, P., and Borrmann, S.: Aerosol mass spectrometry: particle-vaporizer interactions and their consequences for the measurements, Atmos. Meas. Tech., 8, 38113830, https://doi.org/10.5194/amt-8-3811-2015, 2015.

Dyke, P., Coleman, P., and James, R.: Dioxins in ambient air, bonfire night 1994, Chemosphere, 34, 1191-1201, https://doi.org/10.1016/S0045-6535(97)00418-9, 1997.

EEA: Status of black carbon monitoring in ambient air in europe, Luxembourg, available at: http://www.eea.europa. eu/publications/status-of-black-carbon-monitoring (last access: 7 November 2017), 48 pp., 2013.

Elser, M., Huang, R.-J., Wolf, R., Slowik, J. G., Wang, Q., Canonaco, F., Li, G., Bozzetti, C., Daellenbach, K. R., Huang, Y., Zhang, R., Li, Z., Cao, J., Baltensperger, U., El-Haddad, I., and Prévôt, A. S. H.: New insights into $\mathrm{PM}_{2.5}$ chemical composition and sources in two major cities in China during extreme haze events using aerosol mass spectrometry, Atmos. Chem. Phys., 16, 3207-3225, https://doi.org/10.5194/acp-16-3207-2016, 2016.

Faber, P., Drewnick, F., Veres, P. R., Williams, J., and Borrmann, S.: Anthropogenic sources of aerosol particles in a football stadium: Real-time characterization of emissions from cigarette smoking, cooking, hand flares, and color smoke bombs by high-resolution aerosol mass spectrometry, Atmos. Environ., 77, 1043-1051, https://doi.org/10.1016/j.atmosenv.2013.05.072, 2013.

Farmer, D. K., Matsunaga, A., Docherty, K. S., Surratt, J. D., Seinfeld, J. H., Ziemann, P. J., and Jimenez, J. L.: Response of an aerosol mass spectrometer to organonitrates and organosulfates and implications for atmospheric chemistry, P. Natl. Acad. Sci. USA, 107, 6670-6675, https://doi.org/10.1073/pnas.0912340107, 2010.

Farrar, N. J., Smith, K. E. C., Lee, R. G. M., Thomas, G. O., Sweetman, A. J., and Jones, K. C.: Atmospheric emissions of polybrominated diphenyl ethers and other persistent organic pollutants during a major anthropogenic combustion event, Environ. Sci. Technol., 38, 1681-1685, https://doi.org/10.1021/es035127d, 2004.

Faxon, C., Bean, J., and Ruiz, L.: Inland concentrations of cl2 and clno2 in southeast texas suggest chlorine chemistry significantly contributes to atmospheric reactivity, Atmosphere, 6, 1487, https://doi.org/10.3390/atmos6101487, 2015.

Fernandez, P., Grifoll, M., Solanas, A. M., Bayona, J. M., and Albaiges, J.: Bioassay-directed chemical analysis of genotoxic components in coastal sediments, Environ. Sci. Technol., 26, 817-829, https://doi.org/10.1021/es00028a024, 1992.

Florou, K., Papanastasiou, D. K., Pikridas, M., Kaltsonoudis, C., Louvaris, E., Gkatzelis, G. I., Patoulias, D., Mihalopoulos, N., and Pandis, S. N.: The contribution of wood burning and other pollution sources to wintertime organic aerosol levels in two Greek cities, Atmos. Chem. Phys., 17, 3145-3163, https://doi.org/10.5194/acp-17-3145-2017, 2017.

Flowers, B. A., Dubey, M. K., Mazzoleni, C., Stone, E. A., Schauer, J. J., Kim, S.-W., and Yoon, S. C.: Optical-chemicalmicrophysical relationships and closure studies for mixed carbonaceous aerosols observed at Jeju Island; 3-laser photoacoustic spectrometer, particle sizing, and filter analysis, Atmos. Chem. Phys., 10, 10387-10398, https://doi.org/10.5194/acp-10-103872010, 2010.

Fröhlich, R., Crenn, V., Setyan, A., Belis, C. A., Canonaco, F., Favez, O., Riffault, V., Slowik, J. G., Aas, W., Aijälä, M., Alastuey, A., Artiñano, B., Bonnaire, N., Bozzetti, C., Bressi, M., Carbone, C., Coz, E., Croteau, P. L., Cubison, M. J., EsserGietl, J. K., Green, D. C., Gros, V., Heikkinen, L., Herrmann, H., Jayne, J. T., Lunder, C. R., Minguillón, M. C., Mocnik, G., O’Dowd, C. D., Ovadnevaite, J., Petralia, E., Poulain, L., Priestman, M., Ripoll, A., Sarda-Estève, R., Wiedensohler, A., Baltensperger, U., Sciare, J., and Prévôt, A. S. H.: ACTRIS ACSM intercomparison - Part 2: Intercomparison of ME-2 organic source apportionment results from 15 individual, co-located aerosol mass spectrometers, Atmos. Meas. Tech., 8, 2555-2576, https://doi.org/10.5194/amt-8-2555-2015, 2015.

Fry, J. L., Kiendler-Scharr, A., Rollins, A. W., Wooldridge, P. J., Brown, S. S., Fuchs, H., Dubé, W., Mensah, A., dal Maso, M., Tillmann, R., Dorn, H.-P., Brauers, T., and Cohen, R. C.: Organic nitrate and secondary organic aerosol yield from $\mathrm{NO}_{3}$ oxidation of $\beta$-pinene evaluated using a gas-phase kinetics/aerosol partitioning model, Atmos. Chem. Phys., 9, 14311449, https://doi.org/10.5194/acp-9-1431-2009, 2009.

Godri, K. J., Green, D. C., Fuller, G. W., Dall'Osto, M., Beddows, D. C., Kelly, F. J., Harrison, R. M., and Mudway, I. S.: Particulate oxidative burden associated with firework activity, Environ. Sci. 
Technol., 44, 8295-8301, https://doi.org/10.1021/es1016284, 2010.

Hamad, S., Green, D., and Heo, J.: Evaluation of health risk associated with fireworks activity at central london, Air Qual. Atmos. Hlth., 9, 1-7, https://doi.org/10.1007/s11869-015-0384-x, 2015.

Hao, L. Q., Kortelainen, A., Romakkaniemi, S., Portin, H., Jaatinen, A., Leskinen, A., Komppula, M., Miettinen, P., Sueper, D., Pajunoja, A., Smith, J. N., Lehtinen, K. E. J., Worsnop, D. R., Laaksonen, A., and Virtanen, A.: Atmospheric submicron aerosol composition and particulate organic nitrate formation in a boreal forestland-urban mixed region, Atmos. Chem. Phys., 14, 1348313495, https://doi.org/10.5194/acp-14-13483-2014, 2014.

Harrison, M. A. J., Barra, S., Borghesi, D., Vione, D., Arsene, C., and Iulian Olariu, R.: Nitrated phenols in the atmosphere: A review, Atmos. Environ., 39, 231-248, https://doi.org/10.1016/j.atmosenv.2004.09.044, 2005.

Harrison, R. M., Beddows, D. C. S., Hu, L., and Yin, J.: Comparison of methods for evaluation of wood smoke and estimation of UK ambient concentrations, Atmos. Chem. Phys., 12, 82718283, https://doi.org/10.5194/acp-12-8271-2012, 2012.

Jacobson, M. Z.: Isolating nitrated and aromatic aerosols and nitrated aromatic gases as sources of ultraviolet light absorption, J. Geophys. Res.-Atmos., 104, 3527-3542, https://doi.org/10.1029/1998jd100054, 1999.

Jacobson, M. Z.: Effects of biomass burning on climate, accounting for heat and moisture fluxes, black and brown carbon, and cloud absorption effects, J. Geophys. Res.-Atmos., 119, 89809002, https://doi.org/10.1002/2014jd021861, 2014.

Joshi, M., Khan, A., Anand, S., and Sapra, B. K.: Size evolution of ultrafine particles: Differential signatures of normal and episodic events, Environ. Pollut. B, 208, 354-360, https://doi.org/10.1016/j.envpol.2015.10.001, 2016.

Kiendler-Scharr, A., Mensah, A. A., Friese, E., Topping, D., Nemitz, E., Prevot, A. S. H., Äijälä, M., Allan, J., Canonaco, F., Canagaratna, M., Carbone, S., Crippa, M., Dall Osto, M., Day, D. A., De Carlo, P., Di Marco, C. F., Elbern, H., Eriksson, A., Freney, E., Hao, L., Herrmann, H., Hildebrandt, L., Hillamo, R., Jimenez, J. L., Laaksonen, A., McFiggans, G., Mohr, C., O’Dowd, C., Otjes, R., Ovadnevaite, J., Pandis, S. N., Poulain, L., Schlag, P., Sellegri, K., Swietlicki, E., Tiitta, P., Vermeulen, A., Wahner, A., Worsnop, D., and Wu, H. C.: Ubiquity of organic nitrates from nighttime chemistry in the european submicron aerosol, Geophys. Res. Lett., 43, 7735-7744, https://doi.org/10.1002/2016gl069239, 2016.

Kitanovski, Z., Grgic, I., Vermeylen, R., Claeys, M., and Maenhaut, W.: Liquid chromatography tandem mass spectrometry method for characterization of monoaromatic nitro-compounds in atmospheric particulate matter, J. Chromatogr. A, 1268, 35-43, https://doi.org/10.1016/j.chroma.2012.10.021, 2012.

Kostenidou, E., Florou, K., Kaltsonoudis, C., Tsiflikiotou, M., Vratolis, S., Eleftheriadis, K., and Pandis, S. N.: Sources and chemical characterization of organic aerosol during the summer in the eastern Mediterranean, Atmos. Chem. Phys., 15, 11355-11371, https://doi.org/10.5194/acp-15-11355-2015, 2015.

Laskar, S. I., Jaswal, K., Bhatnagar, M. K., and Rathore, L. S.: India meteorological department, India, Proceedings of Indian National Science Academy, 1021-1037, 2016.

Le Breton, M., Bacak, A., Muller, J. B. A., O’Shea, S. J., Xiao, P., Ashfold, M. N. R., Cooke, M. C., Batt, R., Shallcross, D.
E., Oram, D. E., Forster, G., Bauguitte, S. J.-B., Palmer, P. I., Parrington, M., Lewis, A. C., Lee, J. D., and Percival, C. J.: Airborne hydrogen cyanide measurements using a chemical ionisation mass spectrometer for the plume identification of biomass burning forest fires, Atmos. Chem. Phys., 13, 9217 9232, https://doi.org/10.5194/acp-13-9217-2013, 2013.

Le Breton, M., Bacak, A., Muller, J. B. A., Bannan, T. J., Kennedy, O., Ouyang, B., Xiao, P., Bauguitte, S. J. B., Shallcross, D. E., Jones, R. L., Daniels, M. J. S., Ball, S. M., and Percival, C. J.: The first airborne comparison of $\mathrm{N}_{2} \mathrm{O}_{5}$ measurements over the uk using a cims and bbceas during the ronoco campaign, Anal. Methods-UK, 6, 9731-9743, https://doi.org/10.1039/c4ay02273d, 2014a.

Le Breton, M., Bacak, A., Muller, J. B. A., Xiao, P., Shallcross, B. M. A., Batt, R., Cooke, M. C., Shallcross, D. E., Bauguitte, S. J. B., and Percival, C. J.: Simultaneous airborne nitric acid and formic acid measurements using a chemical ionization mass spectrometer around the uk: Analysis of primary and secondary production pathways, Atmos. Environ., 83, 166-175, https://doi.org/10.1016/j.atmosenv.2013.10.008, 2014b.

Lee, B. H., Lopez-Hilfiker, F. D., Mohr, C., Kurtén, T., Worsnop, D. R., and Thornton, J. A.: An iodide-adduct high-resolution timeof-flight chemical-ionization mass spectrometer: Application to atmospheric inorganic and organic compounds, Environ. Sci. Technol., 48, 6309-6317, https://doi.org/10.1021/es500362a, 2014.

Lee, J. D., Whalley, L. K., Heard, D. E., Stone, D., Dunmore, R. E., Hamilton, J. F., Young, D. E., Allan, J. D., Laufs, S., and K1effmann, J.: Detailed budget analysis of HONO in central London reveals a missing daytime source, Atmos. Chem. Phys., 16, 2747-2764, https://doi.org/10.5194/acp-16-2747-2016, 2016.

Liu, D., Whitehead, J., Alfarra, M. R., Reyes-Villegas, E., Spracklen, D. V., Reddington, C. L., Kong, S., Williams, P. I., Ting, Y.-C., Haslett, S., Taylor, J. W., Flynn, M. J., Morgan, W. T., McFiggans, G., Coe, H., and Allan, J. D.: Black-carbon absorption enhancement in the atmosphere determined by particle mixing state, Nat. Geosci., 10, 184-188, https://doi.org/10.1038/ngeo2901, 2017.

Mao, J., Paulot, F., Jacob, D. J., Cohen, R. C., Crounse, J. D., Wennberg, P. O., Keller, C. A., Hudman, R. C., Barkley, M. P., and Horowitz, L. W.: Ozone and organic nitrates over the eastern united states: Sensitivity to isoprene chemistry, J. Geophys. Res.Atmos., 118, 11256-11268, https://doi.org/10.1002/jgrd.50817, 2013.

Mohr, C., DeCarlo, P. F., Heringa, M. F., Chirico, R., Slowik, J. G., Richter, R., Reche, C., Alastuey, A., Querol, X., Seco, R., Peñuelas, J., Jiménez, J. L., Crippa, M., Zimmermann, R., Baltensperger, U., and Prévôt, A. S. H.: Identification and quantification of organic aerosol from cooking and other sources in Barcelona using aerosol mass spectrometer data, Atmos. Chem. Phys., 12, 1649-1665, https://doi.org/10.5194/acp-121649-2012, 2012.

Mohr, C., Lopez-Hilfiker, F. D., Zotter, P., Prevot, A. S. H., Xu, L., Ng, N. L., Herndon, S. C., Williams, L. R., Franklin, J. P., Zahniser, M. S., Worsnop, D. R., Knighton, W. B., Aiken, A. C., Gorkowski, K. J., Dubey, M. K., Allan, J. D., and Thornton, J. A.: Contribution of nitrated phenols to wood burning brown carbon light absorption in detling, united kingdom 
during winter time, Environ. Sci. Technol., 47, 6316-6324, https://doi.org/10.1021/Es400683v, 2013.

Moreno, T., Querol, X., Alastuey, A., Cruz Minguillón, M., Pey, J., Rodriguez, S., Vicente Miró, J., Felis, C., and Gibbons, W.: Recreational atmospheric pollution episodes: Inhalable metalliferous particles from firework displays, Atmos. Environ., 41, 913 922, https://doi.org/10.1016/j.atmosenv.2006.09.019, 2007.

Naeher, L. P., Brauer, M., Lipsett, M., Zelikoff, J. T., Simpson, C. D., Koenig, J. Q., and Smith, K. R.: Woodsmoke health effects: A review, Inhal. Toxicol., 19, 67-106, https://doi.org/10.1080/08958370600985875, 2007.

Ng, N. L., Canagaratna, M. R., Zhang, Q., Jimenez, J. L., Tian, J., Ulbrich, I. M., Kroll, J. H., Docherty, K. S., Chhabra, P. S., Bahreini, R., Murphy, S. M., Seinfeld, J. H., Hildebrandt, L., Donahue, N. M., DeCarlo, P. F., Lanz, V. A., Prévôt, A. S. H., Dinar, E., Rudich, Y., and Worsnop, D. R.: Organic aerosol components observed in Northern Hemispheric datasets from Aerosol Mass Spectrometry, Atmos. Chem. Phys., 10, 46254641, https://doi.org/10.5194/acp-10-4625-2010, 2010.

Ng, N. L., Brown, S. S., Archibald, A. T., Atlas, E., Cohen, R. C., Crowley, J. N., Day, D. A., Donahue, N. M., Fry, J. L., Fuchs, H., Griffin, R. J., Guzman, M. I., Herrmann, H., Hodzic, A., Iinuma, Y., Jimenez, J. L., Kiendler-Scharr, A., Lee, B. H., Luecken, D. J., Mao, J., McLaren, R., Mutzel, A., Osthoff, H. D., Ouyang, B., Picquet-Varrault, B., Platt, U., Pye, H. O. T., Rudich, Y., Schwantes, R. H., Shiraiwa, M., Stutz, J., Thornton, J. A., Tilgner, A., Williams, B. J., and Zaveri, R. A.: Nitrate radicals and biogenic volatile organic compounds: oxidation, mechanisms, and organic aerosol, Atmos. Chem. Phys., 17, 2103-2162, https://doi.org/10.5194/acp-17-2103-2017, 2017.

Paatero, P.: The multilinear engine: A table-driven, least squares program for solving multilinear problems, including the n-way parallel factor analysis model, J. Comput. Graph. Stat., 8, 854888, https://doi.org/10.2307/1390831, 1999.

Paatero, P. and Tapper, U.: Positive matrix factorization: A nonnegative factor model with optimal utilization of error estimates of data values, Environmetrics, 5, 111-126, 1994.

Paglione, M., Kiendler-Scharr, A., Mensah, A. A., Finessi, E., Giulianelli, L., Sandrini, S., Facchini, M. C., Fuzzi, S., Schlag, P., Piazzalunga, A., Tagliavini, E., Henzing, J. S., and Decesari, S.: Identification of humic-like substances (HULIS) in oxygenated organic aerosols using NMR and AMS factor analyses and liquid chromatographic techniques, Atmos. Chem. Phys., 14, 2545, https://doi.org/10.5194/acp-14-25-2014, 2014.

Perring, A. E., Pusede, S. E., and Cohen, R. C.: An observational perspective on the atmospheric impacts of alkyl and multifunctional nitrates on ozone and secondary organic aerosol, Chem. Rev., 113, 5848-5870, https://doi.org/10.1021/cr300520x, 2013.

Pervez, S., Chakrabarty, R. K., Dewangan, S., Watson, J. G., Chow, J. C., and Matawle, J. L.: Chemical speciation of aerosols and air quality degradation during the festival of lights (diwali), Atmos. Pollut. Res., 7, 92-99, https://doi.org/10.1016/j.apr.2015.09.002, 2016.

Petzold, A., Kramer, H., and Schonlinner, M.: Continuous measurement of atmospheric black carbon using a multi-angle absorption photometer, Environ. Sci. Pollut. R., 9, 78-82, 2002.

Priestley, M., Le Breton, M., Bannan, T. J., Leather, K. E., Bacak, A., Allan, J. D., Brazier, T., Reyes-Villegas, E., Shallcross, B. M. A., Khan, M. A., De Vocht, F., Shallcross, B. M., Brazier,
T., Khan, M. A., Allan, J., Shallcross, D. E., Coe, H., and Percival, C. J.: Manchester, uk bonfire night 2014: Air quality and emission ratios during an anthropogenic biomass burning event using a time of flight chemical ionisation mass spectrometer, in preparation, 2018.

Qingguo, H., Liansheng, W., and Shuokui, H.: The genotoxicity of substituted nitrobenzenes and the quantitative structure-activity relationship studies, Chemosphere, 30, 915923, https://doi.org/10.1016/0045-6535(94)00450-9, 1995.

Ravindra, K., Mor, S., and Kaushik, C. P.: Short-term variation in air quality associated with firework events: A case study, J. Environ. Monitor., 5, 260-264, https://doi.org/10.1039/b211943a, 2003.

Reyes-Villegas, E., Green, D. C., Priestman, M., Canonaco, F., Coe, H., Prévôt, A. S. H., and Allan, J. D.: Organic aerosol source apportionment in London 2013 with ME-2: exploring the solution space with annual and seasonal analysis, Atmos. Chem. Phys., 16, 15545-15559, https://doi.org/10.5194/acp-16-155452016, 2016.

Saleh, R., Robinson, E. S., Tkacik, D. S., Ahern, A. T., Liu, S., Aiken, A. C., Sullivan, R. C., Presto, A. A., Dubey, M. K., Yokelson, R. J., Donahue, N. M., and Robinson, A. L.: Brownness of organics in aerosols from biomass burning linked to their black carbon content, Nat. Geosci., 7, 647-650, https://doi.org/10.1038/NGEO2220, 2014.

Sandradewi, J., Prévôt, A. S. H., Szidat, S., Perron, N., Alfarra, M. R., Lanz, V. A., Weingartner, E., and Baltensperger, U. R. S.: Using aerosol light abosrption measurements for the quantitative determination of wood burning and traffic emission contribution to particulate matter, Environ. Sci. Technol., 42, 3316-3323, https://doi.org/10.1021/es702253m, 2008.

Sato, K., Takami, A., Isozaki, T., Hikida, T., Shimono, A., and Imamura, T.: Mass spectrometric study of secondary organic aerosol formed from the photo-oxidation of aromatic hydrocarbons, Atmos. Environ., 44, 1080-1087, https://doi.org/10.1016/j.atmosenv.2009.12.013, 2010.

Slowik, J. G., Vlasenko, A., McGuire, M., Evans, G. J., and Abbatt, J. P. D.: Simultaneous factor analysis of organic particle and gas mass spectra: AMS and PTR-MS measurements at an urban site, Atmos. Chem. Phys., 10, 1969-1988, https://doi.org/10.5194/acp-10-1969-2010, 2010.

Sun, Y. L., Zhang, Q., Schwab, J. J., Yang, T., Ng, N. L., and Demerjian, K. L.: Factor analysis of combined organic and inorganic aerosol mass spectra from high resolution aerosol mass spectrometer measurements, Atmos. Chem. Phys., 12, 8537-8551, https://doi.org/10.5194/acp-12-8537-2012, 2012.

Teich, M., van Pinxteren, D., Wang, M., Kecorius, S., Wang, Z., Müller, T., Mocnik, G., and Herrmann, H.: Contributions of nitrated aromatic compounds to the light absorption of watersoluble and particulate brown carbon in different atmospheric environments in Germany and China, Atmos. Chem. Phys., 17, 1653-1672, https://doi.org/10.5194/acp-17-1653-2017, 2017.

Tian, Y. Z., Wang, J., Peng, X., Shi, G. L., and Feng, Y. C.: Estimation of the direct and indirect impacts of fireworks on the physicochemical characteristics of atmospheric $\mathrm{PM}_{10}$ and $\mathrm{PM}_{2.5}$, Atmos. Chem. Phys., 14, 9469-9479, https://doi.org/10.5194/acp14-9469-2014, 2014.

Tiitta, P., Leskinen, A., Hao, L., Yli-Pirilä, P., Kortelainen, M., Grigonyte, J., Tissari, J., Lamberg, H., Hartikainen, A., Kuuspalo, K., Kortelainen, A.-M., Virtanen, A., Lehtinen, K. E. 
J., Komppula, M., Pieber, S., Prévôt, A. S. H., Onasch, T. B., Worsnop, D. R., Czech, H., Zimmermann, R., Jokiniemi, J., and Sippula, O.: Transformation of logwood combustion emissions in a smog chamber: formation of secondary organic aerosol and changes in the primary organic aerosol upon daytime and nighttime aging, Atmos. Chem. Phys., 16, 13251-13269, https://doi.org/10.5194/acp-16-13251-2016, 2016.

Vassura, I., Venturini, E., Marchetti, S., Piazzalunga, A., Bernardi, E., Fermo, P., and Passarini, F.: Markers and influence of open biomass burning on atmospheric particulate size and composition during a major bonfire event, Atmos. Environ., 82, 218-225, https://doi.org/10.1016/j.atmosenv.2013.10.037, 2014.

Vecchi, R., Bernardoni, V., Cricchio, D., D’Alessandro, A., Fermo, P., Lucarelli, F., Nava, S., Piazzalunga, A., and Valli, G.: The impact of fireworks on airborne particles, Atmos. Environ., 42, 1121-1132, https://doi.org/10.1016/j.atmosenv.2007.10.047, 2008.

Veres, P., Roberts, J. M., Burling, I. R., Warneke, C., de Gouw, J., and Yokelson, R. J.: Measurements of gas-phase inorganic and organic acids from biomass fires by negative-ion proton-transfer chemical-ionization mass spectrometry, J. Geophys. Res.Atmos., 115, D23302, https://doi.org/10.1029/2010jd014033, 2010.

Visser, S., Slowik, J. G., Furger, M., Zotter, P., Bukowiecki, N., Canonaco, F., Flechsig, U., Appel, K., Green, D. C., Tremper, A. H., Young, D. E., Williams, P. I., Allan, J. D., Coe, H., Williams, L. R., Mohr, C., Xu, L., Ng, N. L., Nemitz, E., Barlow, J. F., Halios, C. H., Fleming, Z. L., Baltensperger, U., and Prévôt, A. S. H.: Advanced source apportionment of size-resolved trace elements at multiple sites in London during winter, Atmos. Chem. Phys., 15, 11291-11309, https://doi.org/10.5194/acp-15-112912015, 2015.

Wang, L. W., Wen, L., Xu, C. H., Chen, J. M., Wang, X. F., Yang, L. X., Wang, W. X., Yang, X., Sui, X., Yao, L., and Zhang, Q. Z.: Hono and its potential source particulate nitrite at an urban site in north china during the cold season, Sci. Total Environ., 538, 93-101, https://doi.org/10.1016/j.scitotenv.2015.08.032, 2015.

Wang, Y., Zhuang, G., Xu, C., and An, Z.: The air pollution caused by the burning of fireworks during the lantern festival in beijing, Atmos. Environ., 41, 417-431, https://doi.org/10.1016/j.atmosenv.2006.07.043, 2007.

Washenfelder, R. A., Attwood, A. R., Brock, C. A., Guo, H., Xu, L., Weber, R. J., Ng, N. L., Allen, H. M., Ayres, B. R., Baumann, K., Cohen, R. C., Draper, D. C., Duffey, K. C., Edgerton, E., Fry, J. L., Hu, W. W., Jimenez, J. L., Palm, B. B., Romer, P., Stone, E. A., Wooldridge, P. J., and Brown, S. S.: Biomass burning dominates brown carbon absorption in the rural southeastern united states, Geophys. Res. Lett., 42, 653-664, https://doi.org/10.1002/2014g1062444, 2015.
Weingartner, E., Saathoff, H., Schnaiter, M., Streit, N., Bitnar, B., and Baltensperger, U.: Absorption of light by soot particles: Determination of the absorption coefficient by means of aethalometers, J. Aerosol Sci., 34, 1445-1463, https://doi.org/10.1016/S0021-8502(03)00359-8, 2003.

$\mathrm{Xu}$, L., Suresh, S., Guo, H., Weber, R. J., and Ng, N. L.: Aerosol characterization over the southeastern United States using high-resolution aerosol mass spectrometry: spatial and seasonal variation of aerosol composition and sources with a focus on organic nitrates, Atmos. Chem. Phys., 15, 7307-7336, https://doi.org/10.5194/acp-15-7307-2015, 2015.

Young, D. E., Allan, J. D., Williams, P. I., Green, D. C., Harrison, R. M., Yin, J., Flynn, M. J., Gallagher, M. W., and Coe, H.: Investigating a two-component model of solid fuel organic aerosol in London: processes, $\mathrm{PM}_{1}$ contributions, and seasonality, Atmos. Chem. Phys., 15, 2429-2443, https://doi.org/10.5194/acp15-2429-2015, 2015.

Yuan, B., Liggio, J., Wentzell, J., Li, S.-M., Stark, H., Roberts, J. M., Gilman, J., Lerner, B., Warneke, C., Li, R., Leithead, A., Osthoff, H. D., Wild, R., Brown, S. S., and de Gouw, J. A.: Secondary formation of nitrated phenols: insights from observations during the Uintah Basin Winter Ozone Study (UBWOS) 2014, Atmos. Chem. Phys., 16, 2139-2153, https://doi.org/10.5194/acp16-2139-2016, 2016.

Zhang, J. K., Cheng, M. T., Ji, D. S., Liu, Z. R., Hu, B., Sun, Y., and Wang, Y. S.: Characterization of submicron particles during biomass burning and coal combustion periods in beijing, china, Sci. Total Environ., 562, 812-821, https://doi.org/10.1016/j.scitotenv.2016.04.015, 2016.

Zhang, M., Wang, X., Chen, J., Cheng, T., Wang, T., Yang, X., Gong, Y., Geng, F., and Chen, C.: Physical characterization of aerosol particles during the chinese new year's firework events, Atmos. Environ., 44, 5191-5198, https://doi.org/10.1016/j.atmosenv.2010.08.048, 2010.

Zhu, Q., He, L.-Y., Huang, X.-F., Cao, L.-M., Gong, Z.-H., Wang, C., Zhuang, X., and Hu, M.: Atmospheric aerosol compositions and sources at two national background sites in northern and southern China, Atmos. Chem. Phys., 16, 10283-10297, https://doi.org/10.5194/acp-16-10283-2016, 2016.

Zotter, P., Herich, H., Gysel, M., El-Haddad, I., Zhang, Y., Mocnik, G., Hüglin, C., Baltensperger, U., Szidat, S., and Prévôt, A. S. H.: Evaluation of the absorption Ångström exponents for traffic and wood burning in the Aethalometer-based source apportionment using radiocarbon measurements of ambient aerosol, Atmos. Chem. Phys., 17, 4229-4249, https://doi.org/10.5194/acp17-4229-2017, 2017. 